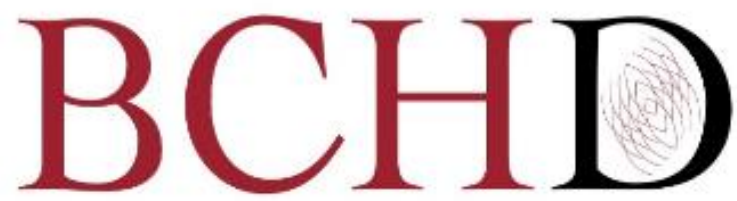

Bioactive Compounds in Health and Disease

\title{
Cnidoscolus aconitifolius: Nutritional, phytochemical composition and health benefits - A review
}

\author{
Anil Panghal ${ }^{1}$, Anjali Onakkaramadom Shaji ${ }^{2}$, Kiran Nain ${ }^{3}$, Mukesh Kumar Garg ${ }^{1}$, Navnidhi \\ Chhikara $^{4 *}$
}

\begin{abstract}
${ }^{1}$ Department of Processing and Food Engineering, AICRP-PHET, Chaudhary Charan Singh Haryana Agricultural University, Hisar, India; ${ }^{2}$ Department of Food Technology and Nutrition, Lovely Professional University, Punjab, India; ${ }^{3}$ Department of Food Technology, Chaudhary Devi Lal University, Sirsa, India; ${ }^{4}$ Department of Food Technology, Guru Jambheshwar University of Science and Technology, Hisar, India
\end{abstract}

*Corresponding Author: Navnidhi Chhikara, PhD, Department of Food Technology, Guru Jambheshwar University of Science and Technology, Hisar, India

Submission Date: November 10 ${ }^{\text {th }}, 2021$; Acceptance Date: November 28 ${ }^{\text {th }}, 2021$; Publication Date: November $30^{\text {th }}, 2021$

Please cite this article as: Panghal A., Shaji A.O., Sajitharan D., Nain K., Garg M.K., Chhikara C. Cnidoscolus aconitifolius: Nutritional, phytochemical composition and health benefits - A review. Bioactive Compounds in Health and Disease 2021; 4(11): 260-286. DOI: https://www.doi.org/10.31989/bchd.v4i11.865

\begin{abstract}
Cnidoscolus aconitifolius belonging to Euphorbiaceae family is widely used as a folk medicine among South American countries such as Mexico and Brazil. C. aconitifolius can be considered as a potential leafy green vegetable, largely due to the presence of various secondary metabolites. Different bioactive compounds such as phenolic acids, Alkaloids, saponins, flavonoids etc. along with terpenoids have unique structure that are exclusive for this genus. $C$. aconitifolius has numerous nutraceutical benefits proven with pharmacological studies such as anti-diabetic, hepatoprotective, antimicrobial etc. The recent upsurge of consumer interest for health promoting products has opened up new vistas for $C$. aconitifolius application in food product research and development field. Limited knowledge about this underutilized plant is presenting an opportunity to explore the plant as novel ingredient with vast functional attributes.
\end{abstract}

Keywords: Cnidoscolus aconitifolius, phytochemicals, nutraceutical potential, biological activity, diabetes 


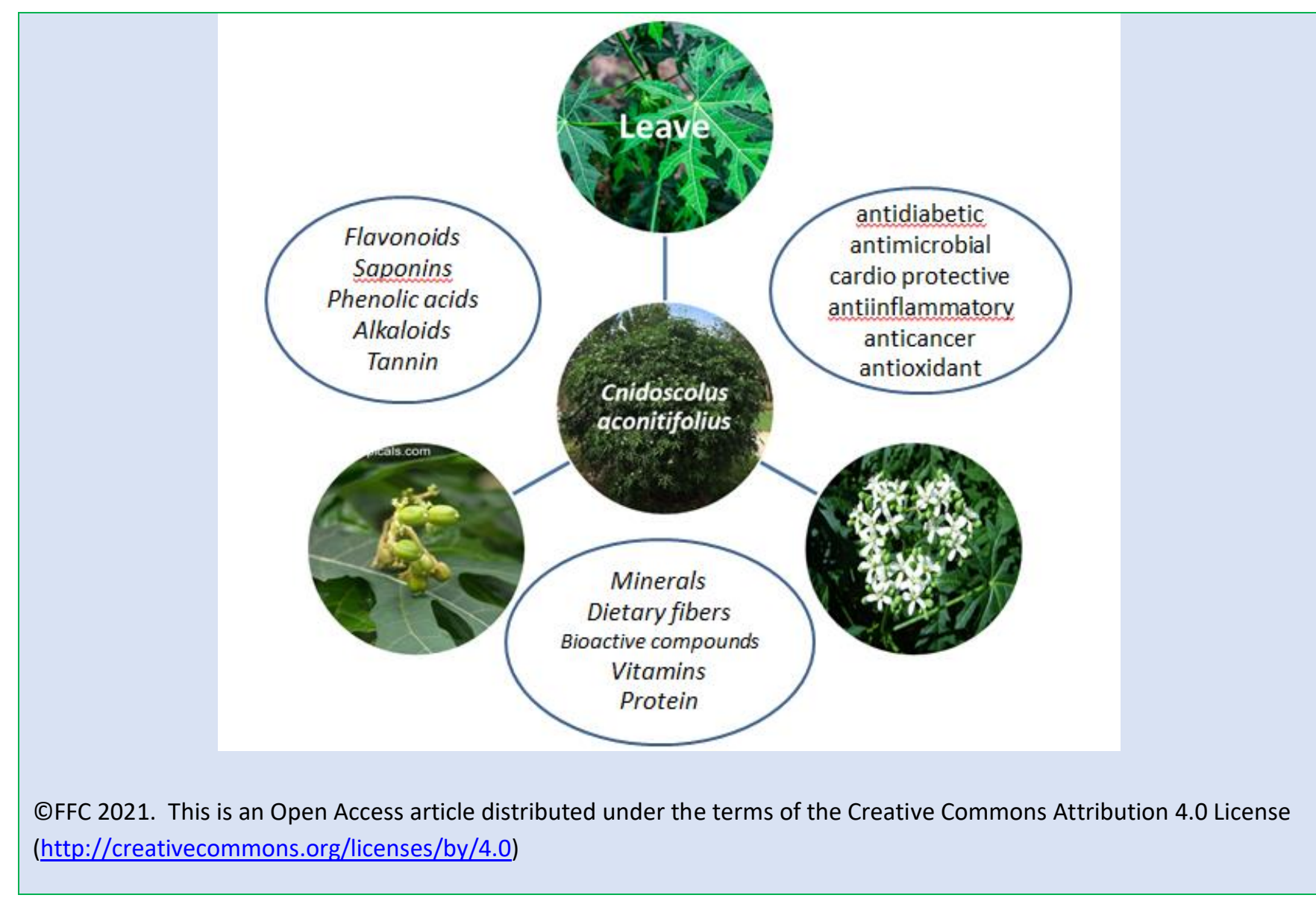

\section{INTRODUCTION}

The concern for improvement in quality of life has increased in the modern world as rates of disease have also steadily increased. Fruits and vegetables have been systematically linked with reduction of risk of chronic diseases such as cardiovascular diseases and neurodegenerative diseases. The demand for health promoting foods has increased among consumers. There is a need for healthy and nutrient rich foods that can improve overall health of the society, which has further increased consumers demand for plant-based foods [1]. Leafy green vegetables are a rich source of nutrients, phytochemicals and other health promoting components. Cnidoscolus aconitifolius (Chaya plant, tree spinach) can be a prime example of a green leafy vegetable that has strong health promoting connotation, an association that is supported by scientific literature. This plant has been associated with several health benefits such as maintaining healthy blood sugar levels, acting as an anti-inflammatory, anti- anemic, anti-microbial, and antioxidant effect etc. [Table 1, Table 2]. Chaya leaf, leaf powder or leaf extract has gained huge importance and thus enhanced the commercial value of the plant. Chaya plant is commonly known as a tree spinach, a member of Euphorbiacae family. Chaya and its related species are a group of arborescent shrubs, of the section calyptosolen of the genus Cnidoscolus. It is a fast-growing attractive shrub, usually 3 to $5 \mathrm{~m}$ tall with attractive, large, dark green leaves. It can grow in a wide range of climates, but at higher temperatures it grows particularly easy and quicker. The leaves have a lower moisture content than most green leafy plants like spinach [2]. Many native plants with high potential health benefits are commonly underutilized and ignored. C. aconitifolius is commonly underutilized due to the poor knowledge regarding its nutritional and health benefits [3]. Tree spinach is exceptionally high in fiber (31.165\%), calcium $(50 \mathrm{mg} / \mathrm{g})$, iron $(10 \mathrm{mg} / \mathrm{g})$, potassium $(20 \mathrm{mg} / \mathrm{g})$ and vitamin $\mathrm{C}$ (892.025 mg/100 g) [4]. It provides a wide range of 
health benefits such as anti-diabetic activity, cardio protective activity, antimicrobials, anti-inflammatory, hematopoietic property and anticancer properties. This comprises the main dietary sources of indigenous people of Yucatan peninsula of Mexico and ketch people [5-6]. While nutritional potential of the chaya plant has been suggested, little scientific experimentation has been done on the nutritional value of chaya leaves. However, there are studies based on therapeutic benefits of chaya. Considering the argument made above, the present work is aimed to compile the available evidence that link the tree spinach and chaya based products with several health promoting properties.

Plant Description: Origin, Distribution and Soil Conditions: Cnidoscolus varieties are of broadly, wildly distributed from southern Texas along the gulf coast, through Yucatan and Chipas, and through Colombia. Chaya has been spread to Maya families in urban and south urban areas throughout Mexico and southwest United States [6]. It has now spread to Cuba, Florida, Mexico, and the US. Throughout the native range, Chaya was typically only cultivated for ornamental or as living fence earlier. Though recently food and medicinal usage of plant have increased due to its inherent nutritional and health promoting attributes. Chaya is cold sensitive and typically grows better in the beginning of the summer months. Chaya flourishes in a wide range of conditions, including extensive sun or rain and humid or dry climates. Remarkably, Chaya plant needs very little care and it grows well on low fertile soil as well. Although it can grow in extreme climates, favorable climates result in good yield and ample leaf production. Chaya plant is easy to propagate and is highly resistant to pests and disease. If it is propagated, it is done by cutting because it roots slowly. At early stages, the growth is low, but soon after leaves are being harvested, growth is rapid.

Morphological Properties: The plant is evergreen in color, drought resistant shrubs up to $6 \mathrm{~m}$ tall with alternate or palmate lobate leaves, milky sap, and small, white flowers on dichotomously branched cymules (Figure1). Chaya plant can grow up to a 5-to-6-meter shrub (Figure 1). But it's recommended to maintain in $2 \mathrm{~m}$ height. Although it's kept very small, it can actively produce great amount of leaf material. The harvest period ranges from two to three months. Leaves are giant and succulent, up to $32 \mathrm{~cm}$ long and $30 \mathrm{~cm}$ wide, on petioles up to $28 \mathrm{~cm}$ long [7]. Leaves exhibit stinging hairs, in petiole and bottom margin of lamina. Mature leaves are mostly three lobed with rough margins and no stinging hairs, young leaves lack the distinct lobes the mature leaves have. Mature plant flowers produce pollen but mostly non-viable. Mature fruit is rare, without viable seed with thick succulent stems.

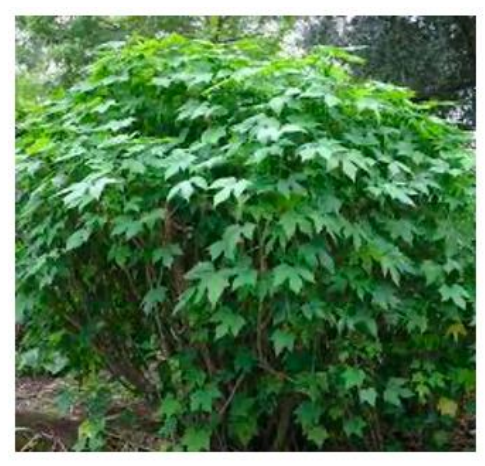

(a)

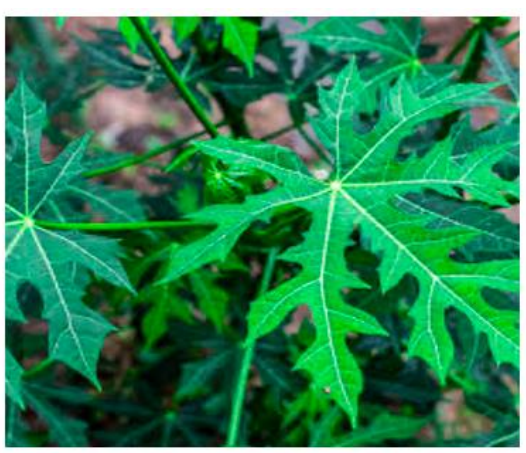

(b)

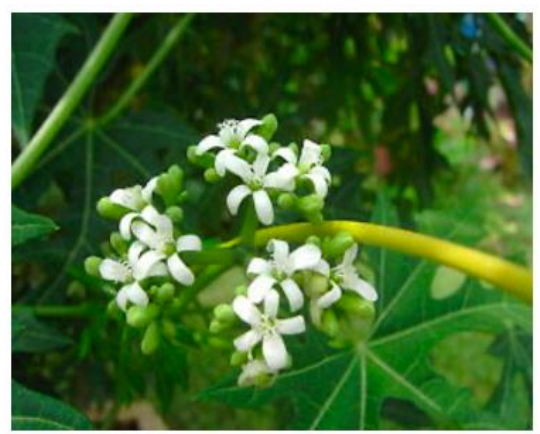

(c)

Figure 1. Cnidoscolus aconitifolius: plant (a); leaves (b); flowers (c). 
Nutritional and Chemical Composition of Tree Spinach:

The leaf protein concentrates of $\mathrm{C}$. aconitifolius contain high amounts of carbohydrate content (41.895\%), $7.68 \%$ of protein, $31.165 \%$ of crude fiber, $4.85 \%$ ash content, $1.145 \%$ crude fat and a moisture content of $13.53 \%$ which can essentially provide a gross energy of 14.6 $\mathrm{MJ} / \mathrm{kg}$ [8-9] (Figure 1). It also contains most of the essential amino acids and vitamins like carotene, vitamin A, vitamin C, niacin, riboflavin, and thiamin. Twenty phyto-chemotypes with different therapeutic activities along with different secondary metabolites such as flavonoids, saponins and Alkaloids are also revealed from C. aconitifolius [10]. Processing generally improved the composition of the tree spinach, and its low moisture content makes it resistant to spoilage microorganisms [11]. Carbohydrate content, crude fiber and its moisture content reveal its nutritional quality. This is also rich in fibers which in turn can stimulate weakening hunger, stimulating peristaltic movements and lower serum cholesterol level. Likewise, dietary fats have a role in food absorption and flavor retention [12]. Chaya leaves when consumed in adequate amounts can meet the RDA values of carbohydrates for children (40\%), adult (40\%), pregnant women (30\%), and lactating women's (25\%). The high fiber- low fat content of tree spinach indicates the clinical relevance in treating digestive associated diseases.

Proteins are essential nutrients needed for the building up of body tissue and regulatory substance such as enzymes and hormone. The quality of protein relays on its amino acid composition, its bioavailability and the essential amino acids that are needed according to RDA of each organism. A total of $44.80 \%$ essential amino acids and $55.19 \%$ non-essential amino acids are present in the leaf protein concentrate of tree spinach [8]. C. aconitifolius leaf contains alanine (4.60 g), arginine (5.17 g), glutamic acid (13.50 g), methionine (1.35 g), histidine (2.60 g), isoleucine (4.25 g), lysine (5.05 g), threonine (3.70 g), tyrosine (3.33 g), aspartic acid (8.50 g), serine (3.36 g), and valine (4.54 g) in 100g of protein [8] (Figure 1).

Micronutrients are essential elements needed in very small quantities, including minerals as well as vitamins. Vitamins are the group of substance that is needed for normal cell function, growth, and development. Chaya leaves contain vitamin A (59.644 $\mathrm{mg} / 100 \mathrm{~g})$, vitamin $\mathrm{C}(892.02 \mathrm{mg} / 100 \mathrm{~g})$, one of the most important categories of vitamins are the B complex vitamins (vitamin $B_{1} 9.425 \mathrm{mg} / 100 \mathrm{~g}$, vitamin $B_{2} 5.84$ $\mathrm{mg} / 100 \mathrm{~g}$, vitamin $\left.\mathrm{B}_{9} 9.425 \mathrm{mg} / 100 \mathrm{~g}\right)$, which are essential for growth, development, and maintenance of other bodily functions [13]. Carotene, riboflavin, and thiamin are also present in C. aconitifolius. [2]. (Table 2). Only $25 \mathrm{~g}$ of Chaya leaves can meet the daily requirement of vitamin $\mathrm{C}$ and can enhance the absorption of non-heme iron [14]. The consumption of Chaya leaves helps to maintain the rigidity of cell membranes and slows down the aging process due to the antioxidant properties possessed by the vitamins [2]. Chaya leaf has high amounts of vitamin C, which serves as a potent antioxidant. This facilitates the transport and uptake of the non heme iron at the mucosa, the reduction of folic acid intermediates, and synthesis of cortisol. Vitamin C deficiency may cause fragility to blood capillaries, gum decay, and scurvy.

Chaya plant also has an appreciable amount of vitamin $A$, which is essential for normal vision, gene expression, growth, and immune function by the 
maintenance of epithelial cell functions. Vitamin $E$ is also an essential vitamin and a powerful antioxidant which can prevent the damage from free radicles. This has also role in formation and normal function of red blood cells and muscles [15-16]. In short, tree spinach is an affordable and nutritious source of vitamins.

The minerals contained in Chaya leaf are essential for maintenance of human health and wellness. It helps in osmoregulation, bone health, hemoglobin formation, prevention of prostate cancer, reduction of stroke etc. The leaf protein concentrate contains sodium of 41.47 $\mathrm{mg} / 100 \mathrm{~g}$, potassium of $33.88 \mathrm{mg} / 100 \mathrm{~g}$, calcium of 29.16 $\mathrm{mg} / 100 \mathrm{~g}$, phosphorus of $24.68 \mathrm{mg} / 100 \mathrm{~g}$, copper of 7.1 $\mathrm{mg} / 100 \mathrm{~g}$, zinc of $15.64 \mathrm{mg} / 100 \mathrm{~g}$, iron of $14.83 \mathrm{mg}$ /100g, manganese of $0.18 \mathrm{mg} / 100 \mathrm{~g}$. Mineral composition of the leaf was affected by the methods of processing (cooking, sun drying) when compared to leaf protein concentrates [3].

Sodium and potassium are the activators of energy potential across nerve membrane and can be used in management of disease associated with the central nervous system and neurodegenerative disease. They also have role in maintaining acid-base balance along with nerve transmissions. Calcium is a rich source of mineral that involved in bone formation. Along with fibrinogen, collagen and fibrin, calcium is an important component in fibrin net formation. Calcium ions along with clotting factor fibrin can help in maintenance of normal nervous function and gut peristalsis [17]. Phosphorus and copper present in tree spinach aid in brain functioning. Chaya leaves can be used as traditional means for increasing blood content of body
[17]. Zinc is an important component for more than ten important enzymatic functions of the body. Deficiency in zinc may result in various health concerns including inability to heal wounds, store insulin, as well as defend against various skin infections. Magnesium is also an essential component in many intermediary metabolism and enzymatic actions. It is an important cell function modulator along with vital role in control of diabetes [18].

Bioactive Compounds: Bioactive compounds are the secondary metabolites present in plant and accounts for numerous health benefits on prolonged consumption in specified amount [1]. Tree spinach contains many bioactive compounds such as phenolic acids, Alkaloids, saponins, flavonoids etc. Terpenoids with unique structures were also identified from C aconitifolius, which is exclusive factor of this genus [19].

Phenolic acids: These are substances containing phenolic ring and an organic carboxylic acid function. The total phenolic content in tree spinach is 33.02 $\mathrm{mg} / 100 \mathrm{~g}$ and can be exploited in pharmaceutical for treatment of many disease conditions [Table 1] [11]. Major phenolic acids that are isolated from the tree spinach are chlorogenic acid, vanillic acid, protocatechuic acid, caftaric acid, 4-hydroxybenzoic acid, caffeic acid, syringic acid, p-caumaric acid, synapic acid and ferulic acid (Figure 2). These phenolic compounds offer antioxidant properties, can prevent cancer and cardiovascular diseases, and possess antimutagenic property [Table 1] [20]. 
<smiles>O=C(O)/C=C/c1ccc(O)c(O)c1</smiles><smiles>COc1cc(C(=O)O)ccc1O</smiles>

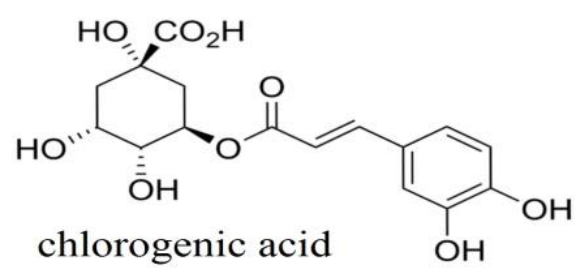<smiles>COc1cc(C(=O)O)cc(OC)c1O</smiles><smiles>COc1cc(/C=C/C(=O)O)cc(O)c1O</smiles>

5-hydroxyferulic acid<smiles>O=C(O)/C=C/c1ccc(O)cc1</smiles><smiles>O=C(/C=C/c1ccc(O)c(O)c1)O[C@H](C(=O)O)[C@@H](O)C(=O)O</smiles>

caftaric acid

Figure 2. Phenolic acids present in Cnidoscolus aconitifolius

Flavonoids: Flavonoids are a group of plant metabolites thought to provide health benefits through cell signaling pathways and antioxidant effects. They are the largest group of phytonutrients with more than 6000 types. Chaya contains abundant amounts of flavonoids (332.89 $\mu g$ catechin equivalents (CE) per gram of sample fresh weight). Yuan et al [21] isolated 15 flavonoids from tree spinach, primarily from the aerial parts. Flavonoids isolated from tree spinach involve procyanidin B1, procyanidin B2, catechin, rutin, gallocatechin gallate, epigallocatechin gallate, epicatechin-3-O-gallate, quercetin-3-0-galactoside, quercetin-3-O-glycoside,
quercetin-3-O-rhamnoside, trans-reverseratol, quercetin and Kaemferol (Figure 3) [Table 3]. These can account for antioxidant properties, play a role in modulation of several enzymatic pathways, reduce the risk of chronic diseases like cancer and cardiovascular disease, and neurodegenerative diseases like Alzheimer's disease, Parkinson's disease, and amyotrophic lateral sclerosis [Table 1]. Flavonoids can neutralize the free radicles and protect against development of heart disease. They can also inhibit tumor invasion and potentially kill growing cancer cells. 
<smiles>O=C(OC1Cc2c(O)cc(O)cc2OC1c1cc(O)c(O)c(O)c1)c1cc(O)c(O)c(O)c1</smiles>

epigallocatechin gallate<smiles>O=c1c(O)c(-c2ccc(O)c(O)c2)oc2cc(O)cc(O)c12</smiles>

kaemferol<smiles>O=c1c(O)c(-c2ccc(O)cc2)oc2cc(O)cc(O)c12</smiles>

quercetin<smiles>O=C(Oc1cc(O)c(O)c(O)c1)C1Cc2c(O)cc(O)cc2OC1c1cc(O)c(O)c(O)c1</smiles>

gallocatechin gallate

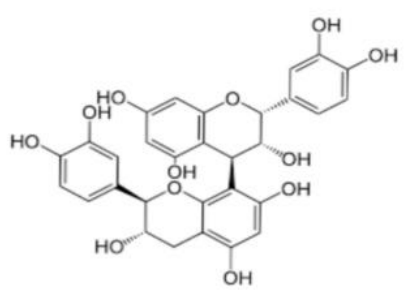

procyanidin B1<smiles>Oc1cc(O)c2c(c1)O[C@H](c1ccc(O)c(O)c1)[C@H](c1c(O)cc(O)c3c1OC(c1ccc(O)c(O)c1)C[C@H]3O)[C@H]2O</smiles>

procyanidin $\mathrm{B} 2$

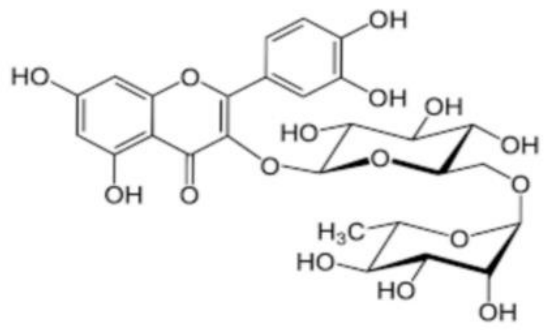

rutin

Figure 3. Flavonoids present in Cnidoscolus aconitifolius

Saponins: These are the class of steroid and terpenoids glycosides and can impart some health benefits in combination with other bioactive compounds. Chaya contains $6.3 .5 \mathrm{mg} / 100 \mathrm{~g}$ and is an anti-nutritional factor associated with tree spinach. Some of the saponins found to be present in tree spinach are:

3-O- $\beta$-d-glucopyranosyl-(1-3)- $\alpha$-L-arabinopyranosyl-

3,23,30-trihydroxyolean-12-en-28-oicacid, 3-O- $\beta$-Dglucopyranosyl-(1-3)- $\beta$-D-galactopyranosyl phytolaccagenic acid, 28-O- $\beta$-D-glucopyranosylester, 3-O-hexose-pentosepentose phytolaccagenicacid-28-O-hexose, 3-O- $\beta$-Dglucopyranosyl-(1-3)- $\alpha$-larabinopyranosyl phytolaccagenic acid 28-O-b-D-glucopyranosylester, 3-O- $\beta$-D-xylopyranosyl(1-3)- $\beta$-D-glucuronopyranosyl hederagenin 28-O- $\beta-D-$ glucopyranosyl ester, 3-O- $\beta$-D-glucopyranosyl-(1-3)- $\alpha$-Larabinopyranosyl serjanic acid 28-O- $\beta$-D-glucopyranosyl ester, 3-O- $\beta$-D-glucuronopyranosyl oleanolic acid 28-O- $\beta$-Dglucopyranosyl ester.

Saponins can provide benefits like boosting the immune system in various ways by offering a chemo preventive strategy in lowering the risk of cancer, lowering blood lipids, lowering blood glucose response, hyperglycemia, hypercholesterolemia, and hypertension [Table 1] [22-23]. Saponins also possess a natural tendency to ward off microbes, which make them effective therapy for fungal and yeast infections [24]. They exhibit antioxidant activity by reducing the level of lipid hydroperoxidase. 
Alkaloids: These are plant secondary metabolites, a class of nitrogenous organic compounds, that are biologically active. There is total of $1.96 \mathrm{mg} / 100 \mathrm{~g}$ of alkaloids content in tree spinach. Choline, trigonelline, palmatine, sitsirikine, dihydrositsirikine, vinblastine, vindoline, catharanthine, vinleurosine (Figure 4) are various alkaloids that have been isolated from Chaya $[22,25]$. These saponins play a role in hepatoprotective

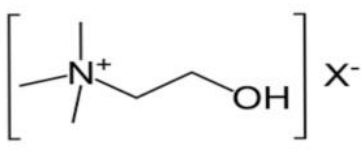

choline
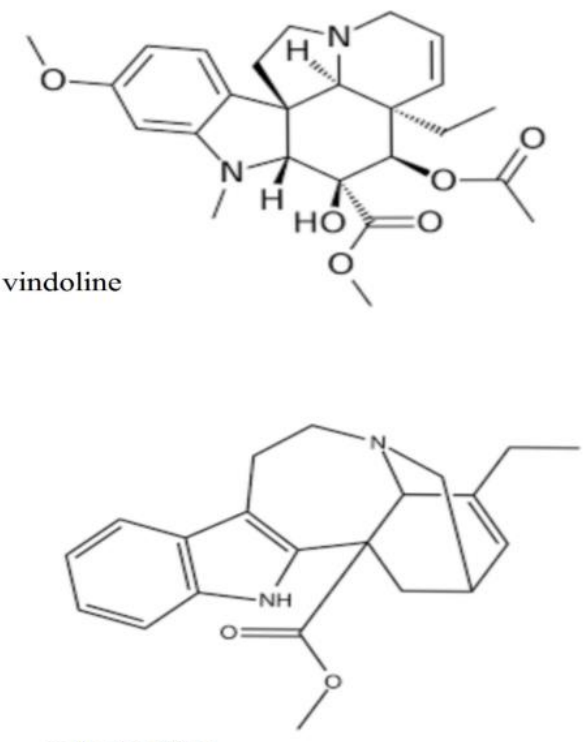

catharanthine

Figure 4. Alkaloids present in Cnidoscolus aconitifolius

Tannins: These are organic substances found in plants and the content can vary with the species, variety, maturity, and season. In tree spinach, it's found that tannins can react with some proteins to provide some tanning effect which is important for the treatment of inflamed or ulcerated tissue [26]. The healing of wound and anti-inflammatory activities is directly linked with tannin content [27]. and anti-inflammatory effects, and in the prevention of various degenerative diseases, and possess free radical scavenging property [Table 3]. This is one of the largest groups of phytochemicals in plants with amazing effects on humans and has been used for treatment of intestinal infections associated with AIDS and hypertension [22].

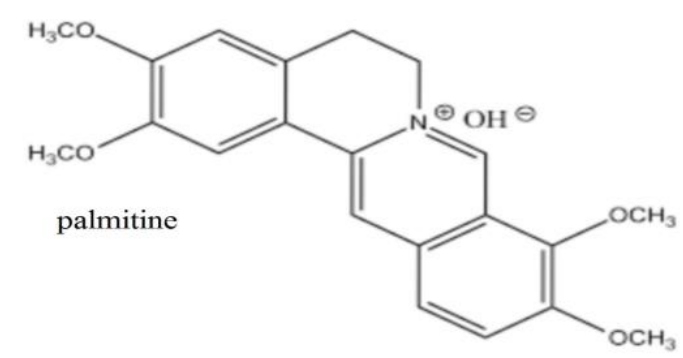<smiles>C[n+]1cccc(C(=O)O)c1</smiles>

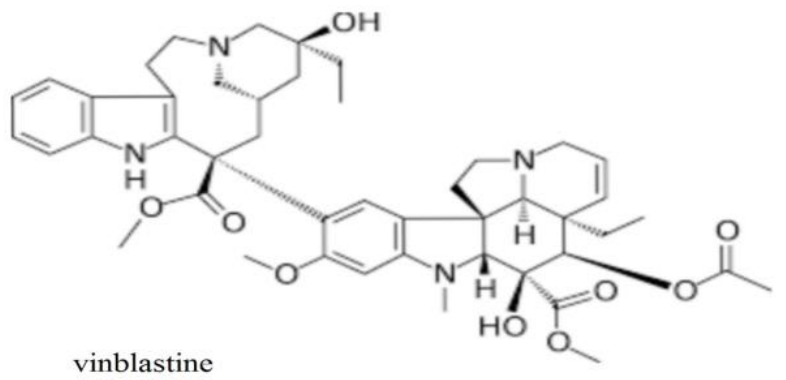

Phenols: These are a class of bioactive compounds consisting of hydroxyl group bonded directly to aromatic hydrocarbon group which accounts for both antimicrobial and antioxidant properties [28]. Total phenolic compounds in tree spinach were found to be $5.66 \mathrm{mg}$ GAE (gallic acid equivalents)/g of fresh weight of sample [29]. Natural polyphenols can remove free radicals, chelating metal catalysts, activate antioxidant enzymes, 
reduce $\alpha$-tocopherol radicals, and inhibit oxidase [Table 1]. Phenolic content of raw Chaya leaves is 241.1 $\mathrm{mg} / 100 \mathrm{~g}$ and that of cooked were $285.1 \mathrm{mg} / 100 \mathrm{~g}$ and the percentage gain of phenolic content was $18.3 \%$. This implies phenolic compounds are trapped in fibers of green leafy vegetables and are more available in cooked compared to raw forms. The percent gain in the total phenol content during cooking may be due to the breakdown of tough cell walls and release of phenolic compounds trapped in fiber of green leafy vegetable for easier absorption in the small intestine [30].

Functional Properties of Tree Spinach: The incidence of chronic diseases such as cancer, diabetes and cardiovascular diseases are increasing worldwide. Human diet and this physiopathology are interlinked and hence there is a huge want for functional foods as a cost-effective mean for prevention and treatment of many diseases. Chaya plant is also used as a traditional medicine for the treatment of diabetes, rheumatism, gastrointestinal disorders, and inflammation [14].

Antioxidant Effect: Antioxidants are substances that inhibit oxidation, mainly used to counter act deterioration of stored food products. Various studies have been conducted over the same to identify the antioxidant potential of the Chaya plant. The presence of bioactive compounds such as phenol and flavonoids can contribute to the antioxidant property. Chronic diseases and food spoilage are associated with prooxidants. The antioxidant components found in Chaya can be effective in disease prevention, food preservation and drug formulations. Kuti and Konuru [31] observed that raw leaves possess more antioxidant potential as compared to cooked sample when evaluated with ORAC (oxygen radical absorbance capacity) assay. The ORAC assay measures a fluorescent signal from a probe that is reduced in the presence of ROS, allowing the fluorescent signal to persist and the results are compared with a standard that is a vitamin $\mathrm{E}$ analogue called Trolox (6-hydroxy-2,5,7,8tetramethylchromane-2-carboxylic acids). Modification in ORAC assay includes the use of fluorescein as a fluorescent probe, for the separation of hydrophilic and lipophilic antioxidants to obtain the total antioxidant capacity.

Synthetic antioxidants like butylated hydroxytoluene (BHT) and butylated hydroxyanisole (BHA) can be tumorigenic [32]. The synthetic counterparts of these antioxidants can be replaced by potential antioxidant compounds that isolated from these kinds of medicinally important plants. The in-vitro antioxidant activities were related against 2,2Diphenylpicryl-1-hydrazyl radicle (DPPH) and vitamin C. This antioxidant potential was due to the phytochemicals present in tree spinach. This antioxidant property in turn facilitates to prevent the oxidative damage occurring in the body.

Anti-Diabetic Property: Diabetes is a metabolic disorder in which the body does not produce or properly use insulin which in turn causes disturbance in carbohydrate, protein and lipid metabolism resulting in number of diseases like retinopathy, blindness, and neuropathies. The hypoglycemic ability and toxicity by the addition of hydroponic Chaya leaves were studied by [33]. Wister albino rats were used for demonstrating the hypoglycemic ability while toxicity in Artemia salina larvae and the results implied that the ingestion of Chaya leaves induced hypoglycemic effect in rats rather than glibenclamide, which is a medication used for type II diabetes. This ameliorative effect was mainly due to the hypoglycemic agents such as catechin and rutin present in Chaya leaves. Infusion of leaves of Chaya can also be considered as non-toxic as well as safe for consumption as a potential hypoglycemic agent [33-34]. The mechanism involved in controlling the high glucose 
level was the presence of major secondary metabolites that can effectively act on $\alpha$-glycosidase enzyme [9] [Table 2].

The anti-diabetic potential of Chaya plant was also studied in streptozotocin-induced diabetic rats [Table 2, Table 3]. The compounds responsible for the antidiabetic property were flavonoids and phenolic acids present in the leaf extracts. This study showed that the hyperglycemic effect produced was not related with or with starch digestive enzymes but with the decrease in glucose absorption. But the long-term intake on these extracts suggests possible alteration in renal function by the increase in urine micro albumin concentration [25].

The ethyl acetate fraction of $C$. aconitifolius can act as an anti- diabetic agent possibly by the inhibition of the carbohydrate metabolism. This can extend the time needed to absorb the glucose and thereby decreasing the level of ingested glucose [35]. The glucose absorption can also be delayed by the inhibition to two major carbohydrate metabolism enzymes such as $\alpha$ amylase and $\alpha$-glycosidase, which are present in the mouth and small intestine [35-36]. The inhibitory effect of ethyl acetate fraction on both enzymes showed a good concentration dependent activity. This inhibitory effect on carbohydrate metabolizing enzyme was possibly due to the presence of phenolic compounds in C. aconitifolius.

In another research approach, extract of $C$. aconitifolius imparted anti-hyperglycemic effect possibly by the presence of flavonoid and saponins that can stimulate insulin from the pancreatic $\beta$ cell [37]. The amount given to the experimental model was 5, 10, 50, $100,150,200 \mathrm{mg} / \mathrm{kg}$ and the best recommended dosage was $100 \mathrm{mg} / \mathrm{kg}$ [Table 3] of body weight.

Protective Effect against Alzheimer: The increased activity of cholinesterase in the brain of patients having Alzheimer's reduces the accessibility of acetylcholine, and thereby imparting a cholinergic shortage and memory loss. Acetyl choline is an important neurotransmitter in cholinergic neurons. Cholinesterase can regulate the neurotransmission through the hydrolysis of acetylcholine. The compounds present in C. aconitifolius especially phenolic compounds such as caumaric acid, amentoflavone, and kaemferol can act on cholinesterase substrate and blocks the enzyme active cite there by alternating the cholinergic dysfunction and less inclination towards Alzheimer's [38].

The inhibition of monoamine oxidase is a vital biomarker for the treatment of Alzheimer disease. The degradation of amines by the reactive oxygen species can be controlled by increasing the neurotransmitters like dopamine. This can be triggered by the decrease in monoamine oxidase level [39]. This inhibition is due to the presence of phenolic compounds in the plant fraction. One of the main reasons for this inhibitory activity is due to structural similarity that is shared by the synthetic monoamine inhibitors towards the phenolic compounds present in ethyl acetate extract of C. aconitifolius [40].

\section{Protective Effect on Neurodegenerative Diseases:} Neurodegenerative disease is marked by the irregular increase in E-NTDase (ecto-5'-nucleotidase) along with neural-inflammation and neuro-immunoreaction [41]. ENTDase can hydrolyze AMP to adenosine and thereby regulate the purinergic transmission and nucleotide mediated cell signaling. The variation in the E-NTDase activity may cause an increase in adenosine level in the synaptic cleft. The increase in levels of adenosine can disturb the release of neurotransmitters like acetylcholine, dopamine, glutamate, and noradrenaline [42]. Adenosine can protect the brain against neural dysfunction. By increasing the accessibility of adenosine to the synaptic cleft the ethyl acetate fraction of Chaya leaves can inhibit the activity of E-NTDase in a 
concentration dependent manner. These inhibitory effects are mainly due to the phenolic compounds that present in the ethyl acetate extract of $C$. aconitifolius [43].

Neurodegenerative diseases are partially due to dopamine deficiencies [44]. L-tyrosine is first converted to L-DOPA (L-3,4-dihydroxyphenyalanine) by Tyrosinase. L-3,4-dihydroxyphenyalanine is then converted to dopamine by DOPA decarboxylase inside the nervous system. The capability of ethyl acetate extract of chaya leaves to inhibit the activity of tyrosinase is linked to the antioxidant properties of phenolic compounds present in plants, which tend to compete with substrates by binding to the active site of enzymes. Thus, the ethyl acetate fraction of $C$. aconitifolius can be used for developing drugs that can be used for treatment of neurodegenerative diseases, as tyrosinase is a critical enzyme for the production of dopamine [43].

The ethyl acetate extract of Chaya leaves increased the $\mathrm{Na}^{+} / \mathrm{K}^{+}$ATPase activity in brain in a concentration dependent manner. $\mathrm{Na}^{+} / \mathrm{K}^{+}$play a significant role in maintaining the membrane potential across cell as well as the neuronal excitability [45]. The ethyl acetate fraction with increased $\mathrm{Na}^{+} / \mathrm{K}^{+}$content may help in preventing the neuronal dysfunction [43].

Protective Effect on Hepatic Damage: The inability of liver to perform its normal physiological function as part of normal physiology or any kind of exposure to harmful chemicals which in turn result in liver failure can be termed as hepatic damage. The protective effect of Chaya leaf extracts against the hepatic damage that induced by the chronic ethanol administration in rats was studied by [46] and study concluded that the ethanol treated rats had high degree of lipid peroxidation. Antioxidant resistant indices such as reduced glutathione and catalases were lowered due to the ethanol activity. At the same time, there was increase in serum cholesterol level, triglycerides, serum alanine, aspartate aminotransferase and low-density lipoproteins in the ethanol treated rats. Rats administered with leaf extracts showcased significant decrease in the liver marker enzymes. A stabilized lipid profile was observable, and it also restored the antioxidant status of ethanol treated rats and thereby indicating the protection against hepatic damage as well as the possible antioxidant effect of Chaya which offered protection against ethanol induced toxicity [46, 34].

Adaramoye and Aluko [46] studied the protective effect on hepatic damage induced by the chronic ethanol administration in-vivo model. The dosage administrated to the experimental model was 100 and $200 \mathrm{mg} / \mathrm{kg}$ of animal body weight. The flavonoids present in the ethanol extract of $C$. aconitifolius can protect the damage caused to glomerular filtration rate by the action of reactive oxygen species. It can also elevate superoxide dismutase (SOD), and catalase activity and thereby protecting the hepatic damage [47]. SOD is an important enzyme that can convert super oxide to hydrogen peroxide and oxygen which in turn fights free radicals. The aqueous extract of Chaya also demonstrated protective effect on carbon tetrachloride induced hepatotoxicity. The phenols, saponins and the cardiac glycosides that present in the extract can prevent the oxidative damage by the carbon tetra chloride by converting them into trichloromethanide in hepatocytes. This can cause cell death by the accumulation of lipid peroxidase, and it also can protect from the inflammatory process [47].

Oyagbemi and Odeitola [48] studied the hepatoprotective effect of ethyl alcohol extract of Chaya leaves and found that hepatic damage is prevented by the inhibition of serum alkaline phosphatase and bilirubin levels by improving the secretary mechanisms of hepatic cells. The amount of ethyl alcohol extract 
given was 100, 500 and $1000 \mathrm{mg} / \mathrm{kg}$ and the best protective effects were shown by the experimental model supplied with $1000 \mathrm{mg} / \mathrm{kg}$.

Antimicrobial Activity: The antimicrobial substances inhibit the growth of microorganism by hindering the essential pathways, physiological metabolic and reproduction activities. The usage of natural antimicrobial agents will reduce the chemical load of food also. The antibacterial activity of $C$. aconitifolius essential oil against three bacterial strains such as Pseudomonas aeruginosa, Escherichia coli and Salmonella typhi was studied using agar disc diffusion technique. The oil exhibited significant antimicrobial activity against $S$. typhi and $E$. coli, but ineffective against $P$. aeruginosa. This proves that essential oil of Chaya leaf has an inhibitory activity against $E$. coli and more particularly against $S$. typhi. This provides a scientific basis for the use of essential oil against typhoid fever and $E$. coli associated with gastroenteritis. The purified active compounds in Chaya can enhance the antimicrobial activity [49] (Table 1).

Antibacterial activity of Chaya was studied in Microplate Alamar Blue Assay in the mycobacterium tuberculosis strain, which is sensitive to streptomycin, isoniazid, rifampicin, Ethambutol, pyrazinamide and against four strains of mycobacterium tuberculosis [50]. Antibacterial activity was again evaluated by many other methods using the aqueous extract of Chaya leaf, but antimicrobial assay turned negative every time [51]. Aqueous extract of the leaf didn't show any kind of inhibitory mechanism against $S$. typhi and Staphylococcus aureus [7]. In later studies, it was found that the hot ethanolic extract of Chaya leaves can contribute to the antimicrobial activity possibly due to the cytotoxic effect associated with the plant alkaloids content. More work is needed to identify the actual mechanism and the compound responsible for this biological activity. This can be step forward in the drug development of alternative natural antimicrobial agents.

The possible antifungal property of Chaya has also been analyzed, and it shown to have inhibit the mycelial growth of test fungi (Aspergillus niger and Aspergillus tamari). Concentration of the extract directly depended on the inhibition zone [52]. A proper study on the antimicrobial potentials of Chaya plant will be a breakthrough in the development of antibiotics with wide range of activity against many allergies and diseases. Thus, the identification of active component responsible for different antimicrobial property may result in innovation of new antimicrobial drugs against pathogenic infection.

Adeniran et al. [11] conducted a study on antimicrobial property of crude ethanol extract of all plant parts such as root, leaves and stem against different bacterial strains (K. oxytoca, Proteus spp., $B$. subtilis, E. coli, P. aeruginosa). All extracts exhibited appreciable activity against $B$. subtilis and $E$. coli. But stem provided antibacterial as well as antibiotics inhibitory activities against almost every bacterial strain used. Acarcidial effect is having a lethal effect on mites. Acarcidial activity of ethanolic extract of $C$. aconitifolius was studied by Numa et al. [53]. 10 to $2000 \mu \mathrm{g}$ of Chaya extract was supplied to the experimental in-vivo model. The possible lethal effect was possibly because of Hamaudol and Xanthones present in ethanolic extract of $C$. aconitifolius. The best recommended dosage was $2000 \mu \mathrm{g} / \mathrm{ml}$.

Hematopoietic Property: Chaya leaves can contribute to the production of blood cells and have hematopoietic properties. This can increase the lifespan of erythrocytes, by reducing the osmotic fragility in protein energy malnutrition [54]. Diseases that can affect blood, especially such as malaria and sickle cell anemia are a burden on health in this developing world. Though 
malaria and sickle cell anemia are entirely different diseases, they also have some common clinical presentations. In both anemia and impaired immune system, there will be excessive generation of free radicles. Vitamin $\mathrm{C}$, vitamin $\mathrm{A}$ and zinc have the capacity to control the impaired growth and immune function which can contribute to cure malaria also. There are studies that show vitamin A can provide host resistant to malaria [55]. Chaya leaves are also enriched with high amounts of vitamins and metal ions also [56], which can be used to treat malaria also. There are many on the treatment of anemia using the micronutrients. Fe, $\mathrm{Zn}$ and $\mathrm{Cu}$ are abundant in Chaya leaves, and this can be utilized in management of sickle cell anemia. Sickling, generation of ROS and decrease in rate of physical development are the major metabolic changes associated with the sickle cell anemia. This metabolic imbalance is associated with stress on erythrocyte membrane resulting to hemolysis and to large extent loss of hemoglobin and essential micronutrients. Minerals ( $\mathrm{Fe}, \mathrm{Zn}, \mathrm{Cu}$ and folate) present in tree spinach can be used to ameliorate such metabolic changes [57]. Iron and copper also have a biological importance. Iron helps in the transport of oxygen as well as metalloenzymes involved in oxidative phosphorylation and copper is essential in proper functioning of these metalloenzymes such as ceruloplasmin involved in iron metabolism. The anti-calcium action of zinc can also contribute to anti-sickling effect [58].

Effect on Erectile Dysfunction: The inhibition of Phosphodiesterase-5 (PDE-5) is key component for penile erectile process. PDE-5 inhibitors such as sildenafil, tadalafil and verdanafil can stimulate and increase the levels of cyclic guanosine monophosphate (cGMP), as well as enhance no bioavailability for the easing of penile tissue for the penile erection. This PDE5 can catalyze the breakdown of cGMP and also reduce the levels of nitric oxide in the endothelial cells and thereby decreasing the signaling [43].

The impairment in penile erection can also be caused by the increased arginase activity, which is associated with diabetic penile corpus cavernosum. Erectile dysfunction can sometimes be found in patients with decreased arginase activity also. This can occur due to the vaso-relaxation of corpus cavernosum smooth muscle. The inhibition of arginase activity can be beneficial method in the treatment of patients with erectile dysfunction. The ethyl acetate extract of Chaya leaves inhibited in arginase activity due to the presence of phenolic compounds present in the fraction and can be considered as a useful treatment to the patients with erectile dysfunction [59-60].

The main reason for the erectile dysfunction is associated with the increased blood pressure or hypertension. This erectile dysfunction is combined with angiotensin II. Increased blood pressure can be managed by decreasing the secretion of angiotensin II by the angiotensin converting enzyme (ACE) inhibitor. This hypertensive induced erectile dysfunction can also be controlled by managing blood pressure through the use of phytochemicals present in Chaya leaves [60].

Antifertility Activity: The effect of Chaya leaf extract on the reproductive hormone of female rats were studied and the administration of extract result in significant increase in serum prolactin concentration and reduction in the serum concentration of estradiol, progesterone, follicle stimulating and luteinizing hormone. Not only that, but it also created an adverse effect on maturation and formation of follicle. Therefore, leaf extract may impair fertility and conception in female rats and can be a potential replacement for the chemical contraceptive agents [61-62]. 
Anticancer Properties: Cancer is the serious concern of developing and developed countries due to hectic lifestyle leading to oxidative stress [63]. The anticancer activity of Chaya was studied using the ethanolic extract at various concentrations against the colon carcinoma cell lines using MTT assay method. The extract showed moderate cytotoxicity over cancerous and normal cell lines. The ethanolic extract was dose dependent and non-selective irrespective of cell origin [22].

Chaya as Animal Feed: Cnidoscolus aconitifolius can be used for animal fed formulations also. The effect of garlic, ginger and Chaya at graded levels on the growth performance, hematological indices and serum biochemistry of pullet chicks were studied [64]. The mixture of chaya leaf along with the ginger and garlic was termed as 'phytomix'. The pullet chicks were supplemented with phytomix at different level. Final weight along with daily weight gain was improved by phytomix supplementation compared to normal soybean based dieted chicks. phytomix was enriched with highest quantity of alkaloids. These compounds played a significant effect on increasing RBC and WBC of the pullet chicks also. The dietary phytomix supplementation up to $10 \mathrm{~g} / \mathrm{kg}$ will generate a positive effect on growth performance and health status of pullet chicks. Supplementation had positive effect on livability of pullet chicks [65]. The palatability and digestion due to stimulation of enzyme secretion, which can increase nutrient role for development of digestive system, muscle tissue accretion, and improve the growth performance. Ginger and garlic can aid the chicks in providing protective mechanism against oxidative damage and decreasing the susceptibility towards infections [66].
Traditional Usage: The use of Chaya leaf as a part of food in Meso America goes back without doubt to preColumbian period [67]. The major parts used for consumption is the leaves, sometimes apical shoots also. The mature leaves were used as wraps. These are consumed mainly after boiling them in water with salt. Cooking time depends approximately 10 to 20 minutes. Broths were also consumed along with greens.

There are many varieties of recipes available with Chaya, but the main one being used along with other vegetables or meat in soup and stews [68]. This is mainly used as a side dish. Chaya tea can be prepared by adding the dried leaves to boiling water along with ginger, honey, and some lemon juice. This is then refrigerated and served. There are several other preparations also by which this healthy diet can be part of our eating habits.

Toxological Aspects of Chaya Plant: Genus Cnidoscolus is well known for their toxological characteristics. This can be toxic to animal as well. High doses in animals can lead to death also. A well grown plant is characterized with the presence of trichomes that can cause an irritating allergic reaction to skin. Raw tree spinach holds high levels of cyanogenic glycosides. These cyanogenic glycosides on hydrolysis liberate hydrogen cyanide (HCN) and cyanide molecules, a potent toxin and anti-nutritional factor. This also suggests that it is a cyanogenic species. The total cyanogenic content in the leaf extract of tree spinach was $2.51 \mathrm{mg} \mathrm{HCN}$ equivalents/ $100 \mathrm{~g}$ fresh weight [69]. The total cyanogen content in fresh leaves of edible tree spinach is relatively lower than the recommended safe level of consumption of food containing cyanoge which is $10 \mathrm{mg} \mathrm{HCN}$ equivalent/g fresh weight. 
Researchers found that the toxicity is because of the presence of hydrocyanic acid and can be decreased by drying processes. The leaves and root bark extracts have low toxicity than other plant parts. The total cyanogen content in fresh leaf tissue is lower when compared to frozen tree spinach [70]. The increased cyanogenic content in freeze product may be due to the freeze induced damage. Freezing can impact on the changes in lipid membrane, intercellular concentration of carbohydrate and even the protein synthesis in plant cell $[69,71]$. High temperature usually lowers the cyanogenic content of the leaves of tree spinach [70].
The predominant cyanogenic glycoside that found tin Cnidoscolus is Linamarin (Figure 5). Various methods can be employed for linamarin determination, but as per the studies of Kuti and Konuru [69], quantification of linamarin by HPTLC method requires fewer amounts of chemicals and recovery degree is great. Linamarin consist of a $\beta$-linkage that can only broke under high pressure or high temperature by the use of mineral acids and enzymes which can cleave the $\beta$ linkage [69, 73]. Linamarin can be hydrolyzed by removing the glucose portion by $\beta$-glycosidase enzyme [73].

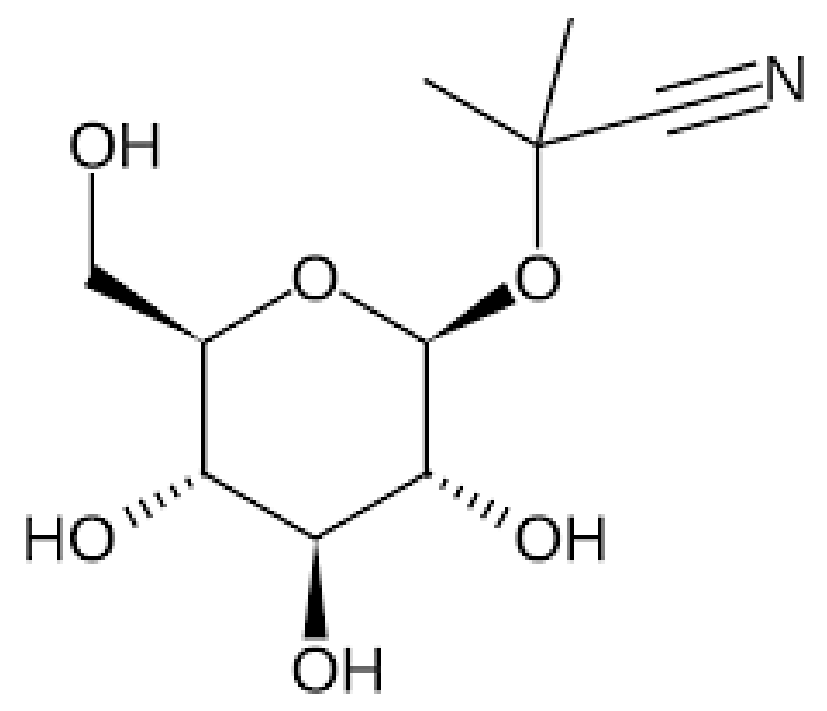

Figure 5. Linamarin- a predominant cyanogenic glycoside in Cnidoscolus aconitifolius

Akachukwu et al. [74] carried out toxicological study from the aqueous extracts of leaves of C.aconitifolius in Wistar rats. These rats were treated with different proportions of therapeutic leaf extracts with their diets for 28 days. After this period also there were no hematological or biochemical changes were observed. The animals treated with the extracts were not affected the toxic effect according to this study suggesting that this plant is not that toxic and can be safely consumed after drying or heat treatment. $\mathrm{HCN}$ is a systemic poison, and its toxicity is due to the inhibition of cytochrome oxidase, which prevents cellular utilization of oxygen, inhibition of terminal step of electron transport in cells of brain results in loss of consciousness, respiratory arrest, and ultimately death. 
Table 1. Biological activities of different constituents of Cnidoscolus aconitifolius

\begin{tabular}{|c|c|c|c|c|}
\hline Name of Constituents & Type & Amount (\%) & Biological Activities & Reference \\
\hline \multicolumn{5}{|l|}{ Fatty acids- $1.145 \%$} \\
\hline n-octadeconoic acid & Steric acid & 8.36 & Flavorant & [75] \\
\hline 9-octadeconoic acid & Oleic acid & 43.13 & $\begin{array}{l}\text { Anti-inflammatory, anti-alopecic, hemolytic, } \\
\text { antitumor, antibacterial, antifungal , lubricant }\end{array}$ & {$[47,75-76]$} \\
\hline n-Hexadecanoic acid & Palmitic acid & 12.82 & $\begin{array}{l}\text { Antioxidant, hypercholestrolemic, lubricant, } \\
\text { nematicide, flavor, anti-androgenic }\end{array}$ & {$[47,75,77]$} \\
\hline $\begin{array}{l}\text { Hexadecanoicacid methyl } \\
\text { ester }\end{array}$ & Palmitic acid & 1.51 & Antioxidant, Hypercholestroemic, lubricant & {$[47,75,77]$} \\
\hline 9,12-octadeconoic acid & Linoleic acid & 43.13 & $\begin{array}{l}\text { Hypercholestroemic, hepatoprotective, anti- } \\
\text { coronary, anti- arthritic }\end{array}$ & {$[75]$} \\
\hline Palmitic (C:16) & \multirow[b]{4}{*}{ Fatty acid } & 2.1 & \multirow{4}{*}{$\begin{array}{l}\text { Profound effects on human disorders and } \\
\text { diseases, prevention against cardiovascular } \\
\text { diseases and cancer }\end{array}$} & \multirow[t]{4}{*}[47,75,77]{} \\
\hline Stearic acid (C:18) & & 1.2 & & \\
\hline Oleic (C 18;1) & & 1.8 & & \\
\hline Linoleic acid(C 18:2) & & 3.3 & & \\
\hline \multicolumn{5}{|l|}{ VITAMIN DERIVATIVES } \\
\hline $\begin{array}{l}\text { Ascorbic acid 2,6- } \\
\text { dihexadecanoate }\end{array}$ & $\begin{array}{l}\text { Vitamin } \\
\text { derivative }\end{array}$ & $\begin{array}{c}12.53 \\
\mathrm{mg} / 100 \mathrm{~g}\end{array}$ & Antioxidant, anti-inflammatory, Antibacterial & {$[52]$} \\
\hline Ascorbic acid & $\begin{array}{l}\text { Vitamin } \\
\text { derivative }\end{array}$ & $\begin{array}{l}892.025 \\
\mathrm{mg} / 100 \mathrm{~g}\end{array}$ & $\begin{array}{l}\text { Antioxidant, absorption of iron, Formation of } \\
\text { collagen, wound healing properties. }\end{array}$ & [2] \\
\hline thiamin & Vitamin B1 & $\begin{array}{r}1.36 \\
\mathrm{mg} / 100 \mathrm{~g}\end{array}$ & $\begin{array}{l}\text { Anti-diabetic, anti-inflammatory, essential for the } \\
\text { flow of electrolytes }\end{array}$ & {$[2,13]$} \\
\hline Niacin & Vitamin B3 & - & $\begin{array}{l}\text { Lowers cholesterol, ease arthritis, boost brain } \\
\text { function }\end{array}$ & [13] \\
\hline $\begin{array}{l}\text { Ascorbic acid -2,6- } \\
\text { dihexadecanoate }\end{array}$ & $\begin{array}{l}\text { Vitamin C } \\
\text { dipalmitate } \\
\text { derivative }\end{array}$ & $\begin{array}{l}12.53 \\
\mathrm{mg} / 100 \mathrm{~g}\end{array}$ & Antioxidant, anti-inflammatory & [15] \\
\hline \multicolumn{5}{|c|}{ PHENOLIC ACID-33.0 mg GAE/ 100g } \\
\hline Chlorogenic acid & Phenolic acid & $\begin{array}{l}3.8 \mathrm{mg} \mathrm{GAE} / \\
100 \mathrm{~g}\end{array}$ & $\begin{array}{l}\text { Antioxidant property, antimutagenic activity, } \\
\text { scavenging activity on free radicles, prevention in } \\
\text { cancer, cardiovascular diseases }\end{array}$ & {$[11,20,25]$} \\
\hline Protocatechuic acid & Phenolic acid & $\begin{array}{l}12.6 \mathrm{mg} \\
\mathrm{GAE} / 100 \mathrm{~g}\end{array}$ & $\begin{array}{l}\text { Antioxidant property, antimutagenic activity, } \\
\text { scavenging activity on free radicles, prevention in } \\
\text { cancer, cardiovascular diseases }\end{array}$ & {$[11,20]$} \\
\hline p-Coumaric acid & Phenolic acid & $\begin{array}{l}33.0 \mathrm{mg} \\
\mathrm{GAE} / 100 \mathrm{~g}\end{array}$ & $\begin{array}{l}\text { Antioxidant property, antimutagenic activity, } \\
\text { scavenging activity on free radicles, prevention in } \\
\text { cancer, cardiovascular diseases }\end{array}$ & {$[11,20]$} \\
\hline Vanillic acid & Phenolic acid & $\begin{array}{l}9.6 \mathrm{mg} \mathrm{GAE} / \\
100 \mathrm{~g}\end{array}$ & $\begin{array}{l}\text { Antioxidant property, antimutagenic activity, } \\
\text { scavenging activity on free radicles, prevention in } \\
\text { cancer, cardiovascular diseases }\end{array}$ & {$[20,25]$} \\
\hline Caftaric acid & Phenolic acid & $\begin{array}{l}14.0 \mathrm{mg} \\
\mathrm{GAE} / 100 \mathrm{~g}\end{array}$ & $\begin{array}{l}\text { Antioxidant property, antimutagenic activity, } \\
\text { scavenging activity on free radicles, prevention in } \\
\text { cancer, cardiovascular diseases }\end{array}$ & {$[20,25]$} \\
\hline 4-Hidroxibenzoic acid & Phenolic acid & $\begin{array}{l}17.7 \mathrm{mg} \\
\mathrm{GAE} / 100 \mathrm{~g}\end{array}$ & $\begin{array}{l}\text { Antioxidant property, antimutagenic activity, } \\
\text { scavenging activity on free radicles, prevention in } \\
\text { cancer, cardiovascular diseases }\end{array}$ & {$[11,20]$} \\
\hline
\end{tabular}




\begin{tabular}{|c|c|c|c|c|}
\hline Name of Constituents & Type & Amount (\%) & Biological Activities & Reference \\
\hline Coutaric acid & Phenolic acid & $\begin{array}{l}20.9 \mathrm{mg} \\
\mathrm{GAE} / 100 \mathrm{~g}\end{array}$ & $\begin{array}{l}\text { Antioxidant property, antimutagenic activity, } \\
\text { scavenging activity on free radicles, prevention in } \\
\text { cancer, cardiovascular diseases }\end{array}$ & {$[20,25]$} \\
\hline Syringic acid & Phenolic acid & $\begin{array}{l}25.5 \mathrm{mg} \\
\mathrm{GAE} / 100 \mathrm{~g}\end{array}$ & $\begin{array}{l}\text { Antioxidant property, antimutagenic activity, } \\
\text { scavenging activity on free radicles, prevention in } \\
\text { cancer, cardiovascular diseases }\end{array}$ & {$[20,25]$} \\
\hline Synapic acid & Phenolic acid & $\begin{array}{l}32.6 \mathrm{mg} \\
\mathrm{GAE} / 100 \mathrm{~g}\end{array}$ & $\begin{array}{l}\text { Antioxidant property, antimutagenic activity, } \\
\text { scavenging activity on free radicles, prevention in } \\
\text { cancer, cardiovascular diseases }\end{array}$ & {$[20,25]$} \\
\hline Caffeic acid & Phenolic acid & $\begin{array}{l}23.5 \mathrm{mg} \\
\mathrm{GAE} / 100 \mathrm{~g}\end{array}$ & $\begin{array}{l}\text { Antioxidant property, antimutagenic activity, } \\
\text { scavenging activity on free radicles, prevention in } \\
\text { cancer, cardiovascular diseases }\end{array}$ & {$[20,25]$} \\
\hline
\end{tabular}

\section{FLAVONOIDS -2.955\%}

\begin{tabular}{|c|c|c|c|c|}
\hline Procyanidin B1 & Flavonoid & $13.4 \%$ & $\begin{array}{l}\text { Role in modulation of several enzymatic } \\
\text { pathways, disease prevention, reduced chronic } \\
\text { diseases including cardiovascular diseases, cancer, } \\
\text { and neurodegenerative disorders, Antioxidant. }\end{array}$ & {$[25,78]$} \\
\hline Gallocatechin gallate & Flavonoid & $38.4 \%$ & $\begin{array}{l}\text { Antioxidant, role in modulation of several } \\
\text { enzymatic pathways, disease prevention, reduced } \\
\text { chronic diseases including cardiovascular diseases, } \\
\text { cancer, and neurodegenerative disorders }\end{array}$ & [78] \\
\hline Epigallocatechin gallate & Flavonoid & $38.4 \%$ & $\begin{array}{l}\text { Role in modulation of several enzymatic } \\
\text { pathways, disease prevention, Antioxidant, } \\
\text { reduced chronic diseases including cardiovascular } \\
\text { diseases, cancer, and neurodegenerative } \\
\text { disorders }\end{array}$ & [78] \\
\hline Epicatechin-3-O-gallate & Flavonoid & $41.8 \%$ & $\begin{array}{l}\text { Role in modulation of several enzymatic } \\
\text { pathways, disease prevention, Antioxidant, } \\
\text { reduced chronic diseases including cardiovascular } \\
\text { diseases, cancer, and neurodegenerative } \\
\text { disorders }\end{array}$ & {$[25,78]$} \\
\hline Catechin & Flavonoid & $17.5 \%$ & $\begin{array}{l}\text { Role in modulation of several enzymatic } \\
\text { pathways, disease prevention, Antioxidant, } \\
\text { reduced chronic diseases including cardiovascular } \\
\text { diseases, cancer, and neurodegenerative } \\
\text { disorders }\end{array}$ & {$[25,78]$} \\
\hline Procyanidin B2 & Flavonoid & $21.2 \%$ & $\begin{array}{l}\text { Role in modulation of several enzymatic } \\
\text { pathways, disease prevention, Antioxidant, } \\
\text { reduced chronic diseases including cardiovascular } \\
\text { diseases, cancer, and neurodegenerative } \\
\text { disorders }\end{array}$ & {$[25,78]$} \\
\hline Rutin & Flavonoid & $27.5 \%$ & $\begin{array}{l}\text { Antioxidant, role in modulation of several } \\
\text { enzymatic pathways, disease prevention, reduced } \\
\text { chronic diseases including cardiovascular diseases, } \\
\text { cancer, and neurodegenerative disorders }\end{array}$ & {$[25,78]$} \\
\hline Quercetin-3-0-gallate & Flavonoid & $41.6 \%$ & $\begin{array}{l}\text { Antioxidant, role in modulation of several } \\
\text { enzymatic pathways, disease prevention, reduced } \\
\text { chronic diseases including cardiovascular diseases, } \\
\text { cancer, and neurodegenerative disorders }\end{array}$ & {$[25,78]$} \\
\hline
\end{tabular}




\begin{tabular}{|c|c|c|c|c|}
\hline Name of Constituents & Type & Amount (\%) & Biological Activities & Reference \\
\hline Quercetin-3-O-galactoside & Flavonoid & $49.6 \%$ & $\begin{array}{l}\text { Role in modulation of several enzymatic } \\
\text { pathways, disease prevention, Antioxidant, } \\
\text { reduced chronic diseases including cardiovascular } \\
\text { diseases, cancer, and neurodegenerative } \\
\text { disorders }\end{array}$ & [78-79] \\
\hline Quercetin-3-O-glycoside & Flavonoid & $50.2 \%$ & $\begin{array}{l}\text { Antioxidant, role in modulation of several } \\
\text { enzymatic pathways, disease prevention, reduced } \\
\text { chronic diseases including cardiovascular diseases, } \\
\text { cancer, and neurodegenerative disorders }\end{array}$ & [78-79] \\
\hline Quercetin-3-0-rhamnoside & Flavonoid & $53.9 \%$ & $\begin{array}{l}\text { Antioxidant, role in modulation of several } \\
\text { enzymatic pathways, disease prevention, reduced } \\
\text { chronic diseases including cardiovascular diseases, } \\
\text { cancer, and neurodegenerative disorders }\end{array}$ & [78-80] \\
\hline Trans- reversatrol & Flavonoid & $59.6 \%$ & $\begin{array}{l}\text { Role in modulation of several enzymatic } \\
\text { pathways, disease prevention, Antioxidant, } \\
\text { reduced chronic diseases including cardiovascular } \\
\text { diseases, cancer, and neurodegenerative } \\
\text { disorders }\end{array}$ & [78-80] \\
\hline Kaempferol & Flavonoid & $70.3 \%$ & $\begin{array}{l}\text { Antioxidant, role in modulation of several } \\
\text { enzymatic pathways, disease prevention, reduced } \\
\text { chronic diseases including cardiovascular diseases, } \\
\text { cancer, and neurodegenerative disorders }\end{array}$ & [78-80] \\
\hline \multicolumn{5}{|l|}{ SAPONINS $-6.305 \mathrm{mg} / 100 \mathrm{~g}$} \\
\hline $\begin{array}{l}\text { 3-O- } \beta \text {-D-glucopyranosyl-(1-- } \\
\text { 3)- } \alpha \text {-L-arabinopyranosyl- } \\
\text { 3,23,30-trihydroxyolean-12- } \\
\text { en-28-oic acid }\end{array}$ & Saponins & $\begin{array}{l}20.9 \\
\mathrm{mg} / 100 \mathrm{~g}\end{array}$ & $\begin{array}{l}\text { Protective effect on } \mathrm{CCl} 4 \text { induced hepatotoxicity } \\
\text { and hematotoxicity, Antihyperglycaemic effect. }\end{array}$ & {$[22,25]$} \\
\hline $\begin{array}{l}\text { 3-O- } \beta \text {-D-xylopyranosyl-(1- } \\
\text { 3)- } \beta \text {-D-glucuronopyranosyl } \\
\text { hederagenin } 28-0-\beta-D- \\
\text { glucopyranosyl ester }\end{array}$ & Saponins & $\begin{array}{l}21.6 \\
\mathrm{mg} / 100 \mathrm{~g}\end{array}$ & $\begin{array}{l}\text { Protective effect on } \mathrm{CCl} 4 \text { induced hepatotoxicity } \\
\text { and hematotoxicity, Antihyperglycaemic effect }\end{array}$ & {$[22,25]$} \\
\hline $\begin{array}{l}\text { 3-O- } \beta \text {-D-glucopyranosyl- } \\
(1 ! 3)-\beta \text {-D-galactopyranosyl } \\
\text { phytolaccagenic acid 28-O- } \\
\beta \text {-D-glucopyranosyl ester }\end{array}$ & Saponins & $\begin{array}{l}22.5 \\
\mathrm{mg} / 100 \mathrm{~g}\end{array}$ & $\begin{array}{l}\text { Protective effect on } \mathrm{CCl} 4 \text { induced hepatotoxicity } \\
\text { and hematotoxicity, Antihyperglycaemic effect }\end{array}$ & {$[80]$} \\
\hline $\begin{array}{l}\text { 3-O-hexose-pentose- } \\
\text { pentose phytolaccagenic } \\
\text { acid 28-0-hexose }\end{array}$ & Saponins & $\begin{array}{l}25.8 \\
\mathrm{mg} / 100 \mathrm{~g}\end{array}$ & $\begin{array}{l}\text { Protective effect on } \mathrm{CCl} 4 \text { induced hepatotoxicity } \\
\text { and hematotoxicity, Antihyperglycaemic effect }\end{array}$ & {$[25]$} \\
\hline $\begin{array}{l}\text { 3-O-b-D-glucopyranosyl- } \\
\text { (1!3)-a-larabinopyranosyl } \\
\text { phytolaccagenic acid 28-0- } \\
\text { b-D-glucopyranosyl ester }\end{array}$ & Saponins & $\begin{array}{l}24.7 \\
\mathrm{mg} / 100 \mathrm{~g}\end{array}$ & $\begin{array}{l}\text { Protective effect on } \mathrm{CCl} 4 \text { induced hepatotoxicity } \\
\text { and hematotoxicity, Antihyperglycaemic effect }\end{array}$ & {$[25]$} \\
\hline \multicolumn{5}{|l|}{ ALKALOIDS-1 $1.96 \mathrm{mg} / 100 \mathrm{~g}$} \\
\hline Choline & Alkaloids & $6.7 \mathrm{mg} / 100 \mathrm{~g}$ & $\begin{array}{l}\text { Prevention in various degenerative diseases, free } \\
\text { radical scavenging property, pharmaceutical } \\
\text { importance. }\end{array}$ & {$[25]$} \\
\hline Catharanthine & Alkaloids & $\begin{array}{l}42.3 \\
\mathrm{mg} / 100 \mathrm{~g}\end{array}$ & $\begin{array}{l}\text { Prevention in degenerative diseases, free radical } \\
\text { scavenging property, pharmaceutical importance. }\end{array}$ & {$[22]$} \\
\hline
\end{tabular}




\begin{tabular}{|c|c|c|c|c|}
\hline Name of Constituents & Type & Amount (\%) & Biological Activities & Reference \\
\hline Trigonelline & Alkaloids & $6.7 \mathrm{mg} / 100 \mathrm{~g}$ & $\begin{array}{l}\text { Prevention in various degenerative diseases, free } \\
\text { radicle scavenging property, pharmaceutical } \\
\text { importance. }\end{array}$ & {$[80]$} \\
\hline Vinleurosine & Alkaloids & $\begin{array}{l}50.6 \\
\mathrm{mg} / 100 \mathrm{~g}\end{array}$ & $\begin{array}{l}\text { Free radicle scavenging property, pharmaceutical } \\
\text { importance }\end{array}$ & [81] \\
\hline Nicotinic acid & Alkaloids & $\begin{array}{l}13.4 \\
\mathrm{mg} / 100 \mathrm{~g}\end{array}$ & $\begin{array}{l}\text { Prevention in various degenerative diseases, free } \\
\text { radicle scavenging property, pharmaceutical } \\
\text { importance. }\end{array}$ & {$[25,81]$} \\
\hline Palmatine & Alkaloids & $\begin{array}{l}15.6 \\
\mathrm{mg} / 100 \mathrm{~g}\end{array}$ & $\begin{array}{l}\text { Free radicle scavenging property, Prevention in } \\
\text { various degenerative diseases }\end{array}$ & {$[25,81]$} \\
\hline Sitsirikine & Alkaloids & $\begin{array}{l}18.5 \\
\mathrm{mg} / 100 \mathrm{~g}\end{array}$ & $\begin{array}{l}\text { Free radicle scavenging property, pharmaceutical } \\
\text { importance }\end{array}$ & {$[22,25,81]$} \\
\hline Vindoline & Alkaloids & $\begin{array}{l}37.7 \\
\mathrm{mg} / 100 \mathrm{~g}\end{array}$ & $\begin{array}{l}\text { Free radicle scavenging property, Prevention in } \\
\text { various degenerative diseases }\end{array}$ & {$[22,25,81]$} \\
\hline Vinleurosine & Alkaloids & $\begin{array}{c}50.6 \\
\mathrm{mg} / 100 \mathrm{~g}\end{array}$ & $\begin{array}{l}\text { Free radicle scavenging property, Prevention in } \\
\text { various degenerative diseases }\end{array}$ & {$[22,25,81]$} \\
\hline Dihydrositssirikine & Alkaloids & $\begin{array}{l}19.9 \\
\mathrm{mg} / 100 \mathrm{~g}\end{array}$ & Pharmaceutical importance & {$[22,25,81]$} \\
\hline \multicolumn{5}{|l|}{ CYCLIC AMINE } \\
\hline $\begin{array}{l}\text { Ү-amino butyric lactam } \\
\text { 6,10,14-trimethyl-2- } \\
\text { Pentadecanone }\end{array}$ & $\begin{array}{l}\text { Pyrrolidone } \\
\text { ketone }\end{array}$ & 0.79 & $\begin{array}{l}\text { Anticonvulsant, solvent and excipient in vetenary } \\
\text { pharmaceutical products. Arthropod repellant }\end{array}$ & [75] \\
\hline \multicolumn{5}{|l|}{ ALCOHOL } \\
\hline 1,2,3-Propanetriol & Glycerol & 0.64 & For pharmaceutical preparations, sweetener & [75] \\
\hline \multicolumn{5}{|l|}{ ACID ESTERS } \\
\hline Hexadecanoic methyl ester & $\begin{array}{l}\text { Palmitic acid } \\
\text { ester }\end{array}$ & 0.82 & $\begin{array}{l}\text { Antioxidant, hypercholestrolemic, flavor, } \\
\text { hemolytic, alpha } 5 \text { reductase inhibitor, } \\
\text { nematicide, lubricant }\end{array}$ & [82] \\
\hline $\begin{array}{l}\text { 1,2,3-propanetriyl ester } \\
\text { octadeconoic acid }\end{array}$ & Trielaidin & 3.86 & For proxisomal metabolism & \\
\hline AMINO ACIDS $-7.68 \%$ & & & & \\
\hline Alanine & \multirow{9}{*}{$\begin{array}{l}\text { Amino } \\
\text { acids }\end{array}$} & $3.5 \%$ & \multirow{9}{*}{$\begin{array}{l}\text { Potential against protein deficiency disease like } \\
\text { kwashiorkor, energy production }\end{array}$} & \multirow[t]{9}{*}{ [8] } \\
\hline Arginine & & $2.3 \%$ & & \\
\hline Glutamic acid & & $1.9 \%$ & & \\
\hline Glutamine & & $2.7 \%$ & & \\
\hline Histidine & & $2.3 \%$ & & \\
\hline Isoleucine & & $1.4 \%$ & & \\
\hline Lysine & & $2.0 \%$ & & \\
\hline Threonine & & $3.2 \%$ & & \\
\hline Valine & & $4.6 \%$ & & \\
\hline
\end{tabular}


Table 2. Functional properties of compounds extracted/compounds isolated from Cnidoscolus aconitifolius

\begin{tabular}{|c|c|c|c|c|c|c|c|}
\hline $\begin{array}{l}\text { Functional } \\
\text { Property }\end{array}$ & $\begin{array}{l}\text { Compound } \\
\text { Responsible }\end{array}$ & $\begin{array}{l}\text { Experimental } \\
\text { model/extract/ } \\
\text { fraction }\end{array}$ & $\begin{array}{l}\text { Experimental } \\
\text { Method }\end{array}$ & $\begin{array}{l}\text { Amount } \\
\text { given }\end{array}$ & $\begin{array}{l}\text { Amount } \\
\text { Recommende } \\
\text { d }\end{array}$ & Mechanism & $\begin{array}{l}\text { Refere } \\
\text { nce }\end{array}$ \\
\hline $\begin{array}{l}\text { Antihyperglycaemic } \\
\text { effect }\end{array}$ & $\begin{array}{l}\text { Flavonoid } \\
\text { Saponins }\end{array}$ & $\mathrm{CHCl}_{3}$ fraction & In vivo & $\begin{array}{l}5,10,50 \\
100,150 \\
\text { and } 200 \\
\mathrm{mg} / \mathrm{kg}\end{array}$ & $100 \mathrm{mg} / \mathrm{kg}$ & $\begin{array}{l}\text { Possibly by stimulating insulin } \\
\text { from pancreatic } \beta \text { cell }\end{array}$ & [37] \\
\hline Anti-anemic effect & $\begin{array}{l}\text { Iron } \\
\text { Vitamin }\end{array}$ & $\begin{array}{l}\text { Dietary } \\
\text { supplementation }\end{array}$ & In vivo & $\begin{array}{l}10 \text { and } \\
20 \%\end{array}$ & $10 \%$ & $\begin{array}{l}\text { Higher reticulosis leads to } \\
\text { increasing mean corpesular } \\
\text { volume results in reduced } \\
\text { osmotic fragility of erythrocytes } \\
\text { and helps in protein energy } \\
\text { metabolism }\end{array}$ & {$[47,54]$} \\
\hline $\begin{array}{l}\text { Hepatoprotective } \\
\text { effect }\end{array}$ & & EtOH extraction & In vivo & $\begin{array}{l}100,500 \\
\text { and } \\
1000 \\
\mathrm{mg} / \mathrm{kg}\end{array}$ & $1000 \mathrm{mg} / \mathrm{kg}$ & $\begin{array}{l}\text { Inhibition of serum ALP and } \\
\text { Bilirubin levels there by } \\
\text { improving secretary mechanism } \\
\text { of hepatic cells }\end{array}$ & {$[47-48]$} \\
\hline $\begin{array}{l}\text { Antibacterial } \\
\text { activity }\end{array}$ & $\begin{array}{l}\text { Alkaloids } \\
\text { Phlobatannins } \\
\text { Flavonoid }\end{array}$ & EtOH extraction & In vitro & $\begin{array}{l}20 \\
\mathrm{mg} / \mathrm{ml}\end{array}$ & & $\begin{array}{l}\text { Showed some sensitivity } \\
\text { towards S.typhi }\end{array}$ & {$[7,47]$} \\
\hline $\begin{array}{l}\text { Antimicrobial } \\
\text { Activity }\end{array}$ & $\begin{array}{l}\text { Alkaloids } \\
\text { Phlobatannins } \\
\text { Flavonoid }\end{array}$ & EtOH extraction & In vitro & $\begin{array}{l}20 \\
\mathrm{mg} / \mathrm{ml}\end{array}$ & & $\begin{array}{l}\text { No sensitivity against bacterial } \\
\text { strains }\end{array}$ & {$[47,52]$} \\
\hline Acarcidial activity & $\begin{array}{l}\text { Hamaudol } \\
\text { Xanthones }\end{array}$ & EtOH extraction & In vitro & $\begin{array}{l}10 \text { to } \\
2000 \\
\mu \mathrm{g} / \mathrm{ml}\end{array}$ & $2000 \mu \mathrm{g} / \mathrm{ml}$ & Lethal effect on mites. & {$[47,53]$} \\
\hline $\begin{array}{l}\text { Anti-nociceptive } \\
\text { and Anti- } \\
\text { inflammatory effect }\end{array}$ & $\begin{array}{l}\text { Terpenoids } \\
\text { Flavonoid }\end{array}$ & EtOH extraction & In vivo & $\begin{array}{l}100 \text { and } \\
200 \mathrm{mg} / \\
\mathrm{kg}\end{array}$ & $200 \mathrm{mg} / \mathrm{kg}$ & $\begin{array}{l}\text { By improving secretary } \\
\text { mechanism }\end{array}$ & {$[37,47]$} \\
\hline $\begin{array}{l}\text { Protective effect on } \\
\mathrm{CCl} 4 \text { induced } \\
\text { hepatotoxicity and } \\
\text { hematotoxicity }\end{array}$ & $\begin{array}{l}\text { Phenols } \\
\text { Saponins } \\
\text { Cardiac } \\
\text { Glycosides }\end{array}$ & $\mathrm{H}_{2} \mathrm{O}$ Extract & In vivo & $\begin{array}{l}100,250 \\
, 500 \\
\text { and } 750 \\
\mathrm{mg} / \mathrm{kg}\end{array}$ & & $\begin{array}{l}\text { Prevents oxidative damage by } \\
\text { metabolism of } \mathrm{CCl} 4 \text { to } \mathrm{CCl} 3 \text { in } \\
\text { hepatocytes which ultimately } \\
\text { results in cell death with } \\
\text { accumulation of lipid } \\
\text { peroxidation and intracellular } \\
\text { calcium ions and triggers } \\
\text { secondary damage from the } \\
\text { inflammatory process }\end{array}$ & {$[47,83]$} \\
\hline Antioxidant activity & $\begin{array}{l}\text { Kaemferol 3- } \\
\text { O glycosides } \\
\text { Quercetin 3- O } \\
\text { glycosides }\end{array}$ & $\mathrm{H}_{2} \mathrm{O}$ Extract & In vitro & Not & $\begin{array}{c}\text { Not } \\
\text { Defined }\end{array}$ & $\begin{array}{l}\text { Combinations with other } \\
\text { flavonoids are producing } \\
\text { synergistic effects }\end{array}$ & [47] \\
\hline $\begin{array}{l}\text { Protective effect on } \\
\text { hepatic damage } \\
\text { induced by chronic } \\
\text { ethanol } \\
\text { administration } \\
\text { model }\end{array}$ & Flavonoids & $\mathrm{H}_{2} \mathrm{O}$ Extract & In vivo & $\begin{array}{l}100 \text { and } \\
200 \\
\mathrm{mg} / \mathrm{kg}\end{array}$ & $200 \mathrm{mg} / \mathrm{kg}$ & $\begin{array}{l}\text { ROS in impairment of the } \\
\text { glomerular filtration rate is } \\
\text { blocked and by elevating } \\
\text { superoxide di maltase (SOD) and } \\
\text { Catalase activity }\end{array}$ & {$[46-47]$} \\
\hline Antioxidant activity & $\begin{array}{l}\text { Kaemferol 3- } \\
\text { O glycosides } \\
\text { Quercetin 3- O } \\
\text { Glycosides }\end{array}$ & Organic extract & In vitro & ND & ND & $\begin{array}{l}\text { Combinations with other } \\
\text { flavonoids are producing } \\
\text { synergistic effects }\end{array}$ & {$[47]$} \\
\hline
\end{tabular}


Table 3. Biological activities of different extracts from Cnidoscolus aconitifolius

\begin{tabular}{|c|c|c|c|}
\hline Extract used & Experimental model & Biological activity or Findings & Reference \\
\hline $\begin{array}{l}\text { Aqueous extract } \\
\text { Cnidoscolus aconitifolius }\end{array}$ & $\begin{array}{l}\text { Preliminary phytochemical } \\
\text { analysis of GC-MS }\end{array}$ & $\begin{array}{l}\text { Remarkable inhibition of bacterial growth, when compared } \\
\text { to chloramphenicol. The major inhibition percentage for } \\
\text { pathogen was } 61.3 \% \text { of chloramphenicol. Alkaloids and } \\
\text { flavonoids were also found using GC-MS contributing to } \\
\text { functional properties of extract. }\end{array}$ & {$[10,84]$} \\
\hline $\begin{array}{l}\text { Aqueous extract } \\
\text { Cnidoscolusaconitifolius }\end{array}$ & $\begin{array}{l}\text { Preliminary phytochemical } \\
\text { analysis and analysis of GC-MS }\end{array}$ & $\begin{array}{l}\text { Presence of cardiac glycosides, flavonoids, phenols, } \\
\text { anthaquinones and triterpenoids was found in } \\
\text { phytochemical analysis. } 42 \text { compounds were identified using } \\
\text { GC-MS and the major ones includes borneol, caryophyllene } \\
\text { oxide, 1H- Cycloprop and azulene, } 4 \text { ( 1-5-dimethyl-4- } \\
\text { enyl)cyclohex-2-enone\%), farnesol, longipinane and } \\
\text { benzene. }\end{array}$ & [84-85] \\
\hline $\begin{array}{l}\text { Aqueous extract } \\
\text { Cnidoscolusaconitifolius }\end{array}$ & $\begin{array}{l}\text { Preliminary phytochemical } \\
\text { analysis and Wistar albino rats }\end{array}$ & $\begin{array}{l}\text { Tannins,alkaloids, saponins, flavonoids, cyanogenic } \\
\text { glycosides and phytates were identified in phytochemical } \\
\text { analysis. Along with the presence of vitamin A, vitaminB1, } \\
\text { vitaminB3, vitaminB6, vitaminB12, vitamin C and vitamin E. } \\
\text { Extract exhibited reversal effect on selected oxidative and } \\
\text { hematological markers. }\end{array}$ & {$[84,86]$} \\
\hline
\end{tabular}

Methanolic extract of Preliminary phytochemical The active fraction which showed the highest hyperglycemic

effect was identified in albino rats was further analysed by GC-MS and identified dodecanoic acid ester-1,2,3propanetrile, cycloteradecane, arachidic acid, octadeconoic acid, 4-propionate, benzene acetic acid, phenyl malonic acid and 3-oxo-4-phenyl butryonitrile.

\begin{tabular}{|c|c|c|c|}
\hline $\begin{array}{l}\text { Ethanolic extract } \\
\text { Cnidoscolus aconitifolius }\end{array}$ & $\begin{array}{l}\text { Preliminary phytochemical } \\
\text { analysis and T.urticae adult } \\
\text { female }\end{array}$ & $\begin{array}{l}\text { The extract was able to increase the mortality and decrease } \\
\text { the fertility in a dose dependent manner. } \\
\text { Major metabolites identified were sesquiterpene type } \\
\text { flavonoid compounds, xanthone type chromone as minor } \\
\text { compounds with potential effect on acaricidas. }\end{array}$ & {$[48,84]$} \\
\hline $\begin{array}{l}\text { Aqueous extract } \\
\text { Cnidoscolus aconitifolius }\end{array}$ & $\begin{array}{l}\text { Preliminary phytochemical } \\
\text { analysis and male albino rats }\end{array}$ & $\begin{array}{l}\text { Reduction of alkaline phosphatase, alanine } \\
\text { aminotransferase, total proteins, total bilirubin, } \\
\text { triglycerides, low-density proteins, urea nitrogen blood, } \\
\text { total cholesterol and creatinine had a significant decrease } \\
\text { and an increase in HDL and complete restoration of plasma } \\
\text { electrolytes. }\end{array}$ & {$[74,84]$} \\
\hline $\begin{array}{l}\text { Methanolic extract } \\
\text { Cnidoscolus aconitifolius }\end{array}$ & $\begin{array}{l}\text { Preliminary phytochemical } \\
\text { analysis and in-silico }\end{array}$ & $\begin{array}{l}\text { The extract supplementation significantly reduced the } \\
\text { activity of liver marker enzymes that elevated by the use of } \\
\text { ethanol, stabilized the lipid profile and restored the status of } \\
\text { treated antioxidants. } \\
\text { The activity of extract was compared with kolaviron in rats } \\
\text { that treated with ethanol and it imparted protective effect } \\
\text { which was proved with histopathological examination of the } \\
\text { liver slides. }\end{array}$ & [84] \\
\hline
\end{tabular}


Extract of Cnidoscolus Wistar albino rats aconitifolius
Methanolic extract of Wistar albino rats Cnidoscolus aconitifolius hepatic injury enzyme maker( serum transaminase (ALT and AST) and phosphatase (ALP) by haloalkane

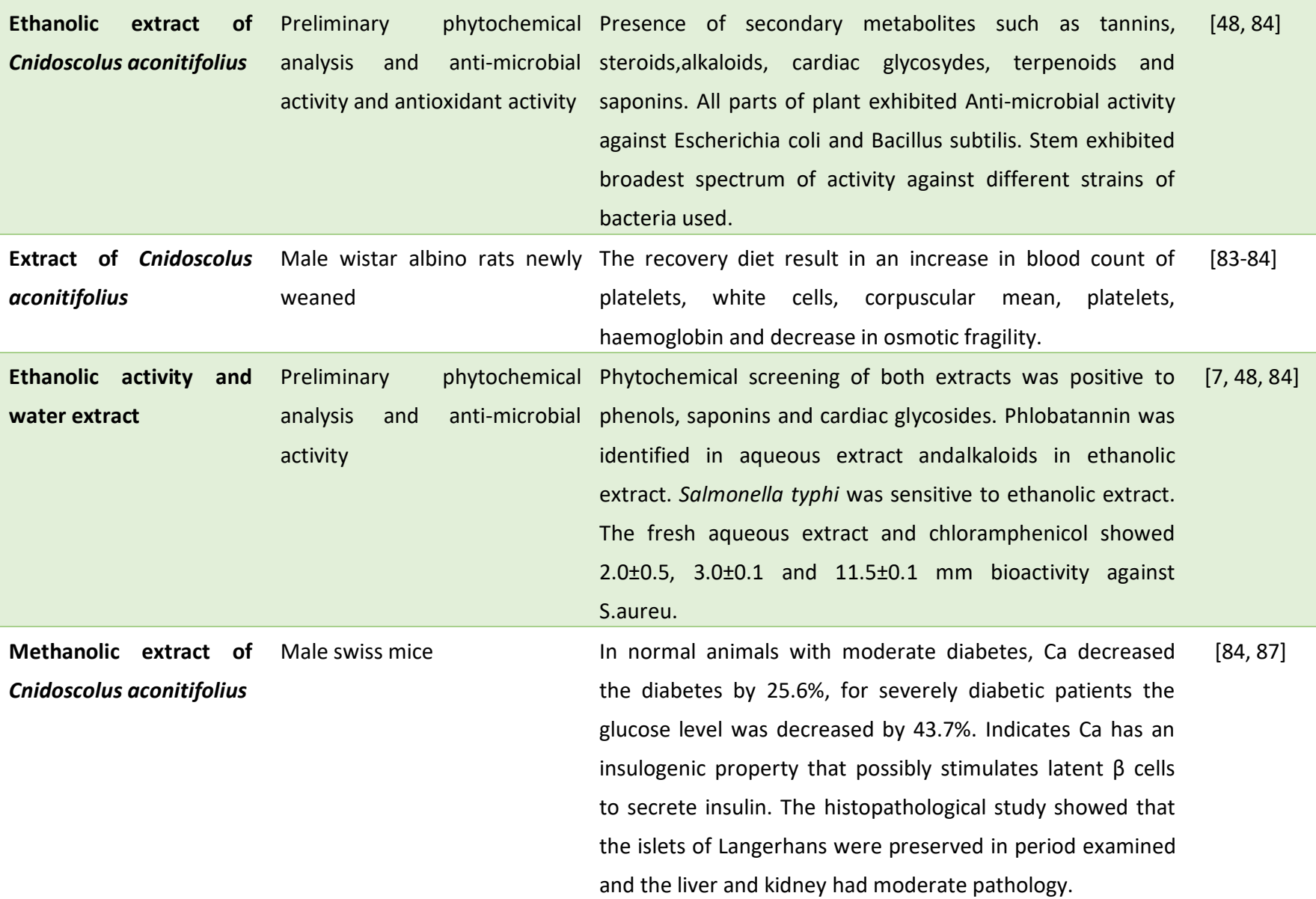

The extract use deceased the biochemical indexes for normal parameters induced by chronic administration of ethanol, the serum and renal malondialdehyde levels increased besides levels of catalase, superoxide dismutase and antioxidant state, there was a reduction of glutathione. These findings contribute to renal protective effect.

Significant reduction in glycemia was shown by the group supplied with $100 \mathrm{mg} / \mathrm{kg}$, along with gradual increase in treatment group compared to diabetic control, which had weight loss. Plasma cholesterol levels also decreased in those treated with $1000 \mathrm{mg} / \mathrm{kg}$ of extract.

Methanolic extract of Wistar albino rats Hematological parameters were restored by the pretreatment, with an associated decrease in activities of

$[48,84]$

$[46,84]$ Cnidoscolus aconitifolius 
richer in nutritional values than spinach, is quite limited. If utilized properly, tree spinach can be a good nutritive and healthy food source to help manage the symptoms of many diseases. Chaya contains lots of secondary metabolites such as alkaloids, flavonoids, saponins, etc. If properly harnessed, this plant can be utilized as a healing aid beyond just the local use and create a worldwide market for its products, either in the production of nutraceutical or pharmaceutical. Overall, the results indicate that, while the evidence that support a useful role of Cnidoscolus aconitifolius consumption in treating many diseases, further human based studies is still needed. Limited knowledge about this underutilized plant is representing an opportunity to investigate new secondary metabolites along with possible functional property that could provide.

List of Abbreviations: CE: catechin equivalents, GAE: gallic acid equivalent, ORAC: oxygen radical absorbance capacity, ROS: Reactive oxygen species, BHT: butylated hydroxytoluene, BHA: butylated hydroxyanisole, DPPH: 2,2-Diphenylpicryl-1-hydrazyl radicle, E-NTDase: ecto-5'nucleotidase, AMP: Adenosine Mono Phosphate, L-

\section{REFERENCES}

1. Panghal, A., Janghu, S., Virkar, K., Gat, Y., Kumar, V. and Chhikara, N., 2018. Potential non-dairy probiotic products-a healthy approach. Food bioscience, 21, 80-89. https://doi.org/10.1016/j.fbio.2017.12.003

2. Berkelaar, D., 2006. Chaya. Technical Note, Echo, Florida.

3. Babalola, John O., and Opeyemi O. Alabi. "Effect of processing methods on nutritional composition, phytochemicals, and antinutrient properties of chaya leaf (Cnidoscolus aconitifolius)." African Journal of Food Science 9, no. 12 (2015): 560-565. https://doi.org/10.5897/AJFS2015.1330

4. Pillai, K.K., Chidambaranathan, N., Halith, M.M., Jayaprakash, S. and Narayanan, N., 2012. Anti-hyperglycemic effect of alcoholic extracts of Cnidoscolus chayamansa in experimental diabetes and their effects on key metabolic enzymes involved in carbohydrate metabolism. International Journal of Research in Pharmacy and Chemistry, 2(1), 164-178.
DOPA: L-3,4-dihydroxyphenyalanine, ATPase: adenosine triphosphatase, SOD: superoxide dismutase, Fe: Iron, Zn: Zinc, Cu: Copper, cGMP: guanosine monophosphate, PDE-5: Phosphodiesterase-5, ACE: angiotensin converting enzyme, MTT: 3-(4,5-dimethylthiazol-2-yl)2,5-diphenyl tetrazolium bromide, RBC: Red blood cell, WBC: white blood cell, HCN: hydrogen cyanide, HPTLC: high pressure thin layer chromatography, RDA: Recommended Dietary Allowance, g: gram, mg: milligram, m: meter, cm: centimeter.

Author's contribution: AP and NC conceived the idea of review. AOS, KN and MKG participated in drafting the manuscript. AP, NC and MKG reviewed the manuscript, and all authors were engaged in drafting and editing the review. All authors have read and approved the final manuscript.

Conflict of Interest: All authors confirm that there are no known conflicts of interest associated with this publication and there has been no financial support for this work that could have influenced its outcome.

Acknowledgment and Funding: The authors declare no acknowledgments / funding.

5. Booth, S., Bressani, R. and Johns, T., 1992. Nutrient content of selected indigenous leafy vegetables consumed by the Kekchi people of Alta Verapaz, Guatemala. Journal of Food composition and Analysis, 5(1), 25-34 https://doi.org/10.1016/0089-1575(92)90005-

6. Ross-Ibarra, J. and Molina-Cruz, A., 2002. The ethnobotany of chaya (Cnidoscolus aconitifolius ssp. aconitifolius Breckon): a nutritious maya vegetable. Economic Botany, 56(4), 350. https://doi.org/10.1663/00130001(2002)056[0350:TEOCCA]2.0.CO;2

7. Awoyinka, O.A., Balogun, I.O., Ogunnowo, A.A., 2007. Phytochemical screening and in vitro bioactivity of Cnidoscolus aconitifolius (Euphorbiaceae). J. Med. Plant. Res. 1, 63-65. https://doi.org/10.4103/0974-8490.138290

8. Victor, M., Abbey, P.A., Joseph, Y., Jonathan, Z., Bobai, Y.K. and Maria, O., 2016. An Underexploited Tropical Plant with Promising Economic Value and the Window of Opportunities 
for Researchers: Cnidoscolus aconitifolius. American Journal of Food Science and Nutrition Research, 3(6), 177.

9. Iyke, W.I., Arthur, N., Bestman, N., Uchenna, N.K. and Numbara, D., 2018. Investigation of Phytocomponents and Hypoglycaemic Effect of Hydro-methanolic Leaf Extract of Cnidoscolus aconitifolius (Spinach Tree) in Streptozotocin Induced-Diabetic Wistar Rats. Journal of Complementary and Alternative Medical Research, 1-9. https://doi.org/10.9734/JOCAMR/2018/26858

10. Iwuji, S.C., Nwafor, A., Azeez, T.O., Nwosu, E.C., Nwaokoro, J.C., Egwurugwu, J. and Danladi, N.B., 2013. Nutritional and Electrolyte Values of Cnidoscolus aconitifolius (Chaya) leaves consumed in Niger Delta, Nigeria. American J Pharm Tech, 3(6), 138-147.

11. Adeniran, O.I., Olajide, O.O., Igwemmar, N.C. and Orishadipe, A.T., 2013. Phytochemical constituents, antimicrobial and antioxidant potentials of tree spinach [Cnidoscolus aconitifolius (Miller) IM Johnston]. Journal of Medicinal Plants Research, 7(19),1310-1316.

12. Ujowundu, C.O., Igwe, C.U., Enemor, V.H.A., Nwaogu, L.A. and Okafor, O.E., 2008. Nutritive and anti-nutritive properties of Boerhavia diffusa and Commelina nudiflora leaves. Pakistan Journal of Nutrition, 7(1), 90-92. https://doi.org/10.3923/pjn.2008.90.92

13. Elfalleh, W., Nasri, N., Marzougui, N., Thabti, I., M'rabet, A., Yahya, Y., Lachiheb, B., Guasmi, F. and Ferchichi, A., 2009. Physico-chemical properties and DPPH-ABTS scavenging activity of some local pomegranate (Punica granatum) ecotypes. International journal of food sciences and nutrition, 60(sup2), 197-210. https://doi.org/10.1080/09637480903067037

14. Sobrinho, T.J.D.S.P., Saraiva, A.M., Almeida, D.M., Tavares, E.A., Pisciottano, M.N.C. and de Amorim, E.L.C., 2017. Phytochemical screening and antibacterial activity of four Cnidoscolus species (Euphorbiaceae) against standard strains and clinical isolates. Journal of Medicinal Plants Research, 6(21), 37423748. https://doi.org/10.5897/JMPR11.1533

15. Jack, M. and Wright, D., 2012. Role of advanced glycation endproducts and glyoxalase $I$ in diabetic peripheral sensory neuropathy. Translational Research, 159(5), 355-365. https://doi.org/10.1016/j.trsl.2011.12.004.

16. Chhikara, N., Kour, R., Jaglan, S., Gupta, P., Gat, Y. and Panghal, A., 2018. Citrus medica: nutritional, phytochemical composition and health benefits-a review. Food \& function, 9(4), 1978-1992. https://doi.org/10.1039/c7fo02035j

17. Singh, V. and Garg, A.N., 2006. Availability of essential trace elements in Indian cereals, vegetables and spices using INAA and the contribution of spices to daily dietary intake. Food chemistry, 94(1), 81-89.

https://doi.org/10.1016/j.foodchem.2004.10.053

18. Akindahunsi, A.A. and Salawu, S.O., 2005. Phytochemical screening and nutrient-antinutrient composition of selected tropical green leafy vegetables. African Journal of Biotechnology, 4(6), 497-501

19. Cateni, F., Falsone, G. and Zilic, J., 2003. Terpenoids and glycolipids from Euphorbiaceae. Mini reviews in medicinal chemistry, 3(5), 425-437. https://doi.org/10.2174/1389557033487971

20. Ozcan, T., Akpinar-Bayizit, A., Yilmaz-Ersan, L. and Delikanli, B., 2014. Phenolics in human health. International Journal of chemical engineering and applications, 5(5),393. https://doi.org/10.7763/IJCEA.2014.V5.416

21. Yuan, W., Li, S., Ownby, S., Zhang, Z., Wang, P., Zhang, W. and Beasley, R.S., 2007. Flavonoids, coumarins and triterpenes from the aerial parts of Cnidoscolus texanus. Planta medica, 73(12), 1304-1308. https://doi.org/10.1055/s-2007-990226

22. Yakubu, M.T., Akanji, M.A., Oladiji, A.T., Olatinwo, A.W.O., Adesokan, A.A., Yakubu, M.O., Owoyele, B.V., Sunmonu, T.O. and Ajao, M.S., 2008. Effect of Cnidoscolous aconitifolius (Miller) IM Johnston leaf extract on reproductive hormones of female rats.

23. Trease, G.E. and W.C. Evans, 1985. Pharmacognosy, (13 ${ }^{\text {th }}$ edn.) Bailliere Tindall Ltd 60-75.

24. Price, K.R., Johnson, I.T., Fenwick, G.R. and Malinow, M.R., 1987. The chemistry and biological significance of saponins in foods and feedingstuffs. Critical Reviews in Food Science \& Nutrition, 26(1), 27-135. https://doi.org/10.1080/10408398709527461

25. Ramos-Gomez, M., Figueroa-Pérez, M. G., Guzman-Maldonado, H., Loarca-Piña, G., Mendoza, S., Quezada-Tristán, T., \& Reynoso-Camacho, R. (2017). Phytochemical profile, antioxidant properties and hypoglycemic effect of chaya (Cnidoscolus chayamansa) in Stz-induced diabetic rats. Journal of Food Biochemistry, 41(1), e12281.

https://doi.org/10.1111/ffbc.12281

26. Parekh, J. and Chanda, S., 2007. In vitro antibacterial activity of the crude methanol extract of Woodfordia fruticosa Kurz. Flower (Lythraceae). Brazilian Journal of Microbiology, 38(2), 204-207. https://doi.org/10.1590/\$1517-83822007000200004

27. de Sousa Araújo, T. A., Alencar, N. L., de Amorim, E. L. C., \& de Albuquerque, U. P. (2008). A new approach to study medicinal plants with tannins and flavonoids contents from the local knowledge. Journal of ethnopharmacology, 120(1), 72-80. https://doi.org/10.1016/j.jep.2008.07.032 
28. Chhikara, N., Kushwaha, K., Sharma, P., Gat, Y. and Panghal, A., 2018. Bioactive compounds of beetroot and utilization in food processing industry: A critical review. Food chemistry. https://doi.org/10.1016/j.foodchem.2018.08.022

29. Jiménez-Aguilar, D.M. and Grusak, M.A., 2015. Evaluation of minerals, phytochemical compounds and antioxidant activity of Mexican, Central American, and African green leafy vegetables. Plant foods for human nutrition, 70(4), 357-364. https://doi.org/10.1007/s11130-015-0512-7

30. Panghal, A., Kaur, R., Janghu, S., Sharma, P., Sharma, P., \& Chhikara, N. (2019). Nutritional, phytochemical, functional and sensorial attributes of Syzygium cumini L. pulp incorporated pasta. Food chemistry, 289, 723-728. https://doi.org/10.1016/j.foodchem.2019.03.081

31. Kuti, J.O. and Konuru, H.B., 2011. Antioxidant capacity and phenolic content in leaf extracts of tree spinach (Cnidoscolus spp.). Journal of Agricultural and Food Chemistry, 52(1), 117121. https://doi.org/10.1021/jf030246y

32. Ito, N., Fukushima, S. and Tsuda, H., 1985. Carcinogenicity and modification of the carcinogenic response by $\mathrm{BHA}, \mathrm{BHT}$, and other antioxidants. CRC Critical reviews in Toxicology, 15(2), 109-150. https://doi.org/10.3109/10408448509029322

33. Soto, V. R., Morales Rubio, M. E., Verde Star, M. J., Oranday Cárdenas, A., Preciado-Rangel, P., Antonio González, J., \& Esparza-Rivera, J. R. (2015). Cnidoscolus chayamansa organic hydroponic and its hypoglycemic capacity, nutraceutical quality and toxicity. Revista mexicana de ciencias agrícolas, 6(4), 815825.

34. de Oliveira-Junior, R. G., Ferraz, C. A. A., de Oliveira, A. P., Araújo, C. S., da Silva Oliveira, L. F., Picot, L., ... \& da Silva Almeida, J. R. G. (2018). Phytochemical and pharmacological aspects of Cnidoscolus Pohl species: A systematic review. Phytomedicine, 50, 137-147. https://doi.org/10.1016/j.phymed.2017.08.017

35. Ojo, O.A., Ajiboye, B.O., Ojo, A.B., Olayide, I.I., Akinyemi, A.J., Fadaka, A.O., Adedeji, E.A., Boligon, A.A. and de Campos, M.M.A., 2018. HPLC-DAD Fingerprinting Analysis, Antioxidant Activity of Phenolic Extracts from Blighia sapida Bark and Its Inhibition of Cholinergic Enzymes Linked to Alzheimer's Disease. Jordan Journal of Biological Sciences, 10(4), 257-264

36. Ajiboye, B.O., Ojo, O.A., Adeyonu, O., Imiere, O., Olayide, I., Fadaka, A. and Oyinloye, B.E., 2016. Inhibitory effect on key enzymes relevant to acute type- 2 diabetes and antioxidative activity of ethanolic extract of Artocarpus heterophyllus stem bark. Journal of acute disease, 5(5), 423-429.

https://doi.org/10.1016/j.joad.2016.08.011

37. Samuel, I., Nwafor, A., Egwurugwu, J., Henrietta, C., 2014. Antihyperglycaemic Efficacy of Cnidoscolus aconitifolius compared with Glibenclamide in Alloxan-induced Diabetic Wistar Rats. Int. Res. J. Med. Sci. 2, 1-4.

38. Nordberg, A., Ballard, C., Bullock, R., Darreh-Shori, T. and Somogyi, M., 2013. A review of butyrylcholinesterase as a therapeutic target in the treatment of Alzheimer's disease. The primary care companion for CNS disorders, 15(2).

https://doi.org/10.4088/PCC.12r01412

39. Thomas, T., 2000. Monoamine oxidase-B inhibitors in the treatment of Alzheimers disease. Neurobiology of aging, 21(2), 343-348. https://doi.org/10.1016/s0197-4580(00)00100-7

40. Benamar, H., Rached, W., Derdour, A. and Marouf, A., 2010. Screening of Algerian medicinal plants for acetylcholinesterase inhibitory activity. Journal of Biological Sciences, 10(1), 1-9. https://doi.org/10.3923/jbs.2010.1.9

41. Burnstock, G. (2008). Purinergic signalling and disorders of the central nervous system. Nature reviews Drug discovery, $7(7)$, 575-590. https://doi.org/10.1038/nrd2605

42. Oboh, G., Olasehinde, T.A. and Ademosun, A.O., 2014. Essential oil from lemon peels inhibit key enzymes linked to neurodegenerative conditions and pro-oxidant induced lipid peroxidation. Journal of oleo science, 13166.

https://doi.org/10.5650/jos.ess13166

43. Ajiboye, B.O., Ojo, O.A., Okesola, M.A., Oyinloye, B.E. and Kappo, A.P., 2018. Ethyl acetate leaf fraction of Cnidoscolus aconitifolius (Mill.) IM Johnst: antioxidant potential, inhibitory activities of key enzymes on carbohydrate metabolism, cholinergic, monoaminergic, purinergic, and chemical fingerprinting. International Journal of Food Properties, 21(1),1697-1715. https://doi.org/10.1080/10942912.2018.1504787

44. Meiser, J., Weindl, D., \& Hiller, K. (2013). Complexity of dopamine metabolism. Cell Communication and Signaling, 11(1), 1-18. https://doi.org/10.1186/1478-811X-11-34

45. Wyse, A.T., Bavaresco, C.S., Reis, E.A., Zugno, A.I., Tagliari, B., Calcagnotto, T. and Netto, C.A., 2004. Training in inhibitory avoidance causes a reduction of $\mathrm{Na}+, \mathrm{K}+$-ATPase activity in rat hippocampus. Physiology \& behavior, 80(4), 475-479. https://doi.org/10.1016/j.physbeh.2003.10.002

46. Adaramoye, O.A., Aluko, A. and Oyagbemi, A.A., 2011. Cnidoscolus aconitifolius leaf extract protects against hepatic damage induced by chronic ethanol administration in Wistar rats. Alcohol and alcoholism, 46(4), 451-458. https://doi.org/10.1093/alcalc/agr060

47. Samuel, I., Arthur, N., Jude, E., \& Henrietta, C. (2014). Antihyperglycaemic efficacy of Cnidoscolus aconitifolius 
compared with glibenclamide in alloxan-induced diabetic Wistar rats. Intl. Res. J. Med. Sci, 2(3), 1-4.

48. Oyagbemi, A.A., Odetola, A.A., 2010. Hepatoprotective effects of ethanolic extract of Cnidoscolus aconitifolius on paracetamol-induced hepatic damage in rats. Pak. J. Biol. Sci. 13, 164-169 https://doi.org/10.3923/pjbs.2010.164.169

49. Omikorede, O., Kasali, A.A., Eshilokun, A.O. and Iwuchukwu, I.N., 2006. Antimicrobial activity of the essential oil of Cnidoscolous aconitifolius (Fam. Euphorbiaceae) leaf. Journal of Essential Oil Bearing Plants, 9(3), 300-303. https://doi.org/10.1080/0972060X.2006.10643508

50. Ohadoma, S. C. "Phytochemical constituents and antibacterial activities of aqueous and hydromethanolic leaf extracts of chaya (cnidoscolus aconitifolius)." Futo J. Ser. 2 (2016): 195204.

51. Ekeleme, U. G., N. C. Nwachukwu, A. C. Ogodo, C. J. Nnadi, I. A. Onuabuchi, and K. U. Osuocha. "Phytochemical screening and antibacterial activity of Cnidoscolus aconitifolius and associated changes in liver enzymes in wistar rats." Australian Journal of Basic and Applied Sciences 7, no. 12 (2013): 156-162.

52. Oyagbemi, A.A., Ogunleye, A.O., Lawal, T.O. and Azeez, I.O., 2011. The effect of Cnidoscolus aconitifolius on multi-drug resistant micro-organisms. African Journal of Biotechnology, 10(3), 413-415.

https://doi.org/10.5897/AJB10.353

53. Numa, S., Rodríguez, L., Rodríuez, D., Coy-Barrera, e., 2015. Susceptibility of Tetranychus urticae Koch to an ethanol extract of Cnidoscolus aconitifolius leaves under laboratory conditions. Springer. Plus. 4, 338-348. https://doi.org/10.1186/s40064-015-1127-z

54. Oyagbemi, A.A., Odetola, A.A. and Azeez, O.I., 2008. Ameliorative effects of Cnidoscolus aconitifolius on anaemia and osmotic fragility induced by proteinenergy malnutrition. African journal of biotechnology, 7(11). https://doi.org/10.5897/AJB08.247

55. Smith, Todd G., Kodjo Ayi, Lena Serghides, Caroline D. Mcallister, and Kevin C. Kain. "Innate immunity to malaria caused by Plasmodium falciparum." Clinical and Investigative Medicine 25, no. 6 (2002): 262.

56. Uthman, Ed. Understanding anemia. Univ. Press of Mississippi, 2009.

57. Shankar, A.H. and Prasad, A.S., 1998. Zinc and immune function: the biological basis of altered resistance to infection. The American journal of clinical nutrition, 68(2), 447S-463S. https://doi.org/10.1093/ajcn/68.2.447S

58. Das, A. K. "A textbook on medinicinal aspects of Bioinorganic Chemistry. CBS Publishers and Distributors India." (1990): 5-9.
59. Shin, Y.S., Zhao, C., Zhang, L.T. and Park, J.K., 2015. Current status and clinical studies of oriental herbs in sexual medicine in Korea. The world journal of men's health, 33(2), 62-72. https://doi.org/10.5534/wjmh.2015.33.2.62

60. Akomolafe, Seun, Ganiyu Oboh, Tosin Olasehinde, Sunday Oyeleye, and Opeyemi Ogunsuyi. "Modulatory effects of aqueous extract from Tetracarpidium conophorum leaves on key enzymes linked to erectile dysfunction and oxidative stressinduced lipid peroxidation in penile and testicular tissues." $J$ Appl Pharm Sci 7, no. 01 (2017): 051-056. https://doi.org/10.7324/JAPS.2017.70107

61. Dong, C.X., Hayashi, K., Lee, J.B. and Hayashi, T., 2010. Characterization of structures and antiviral effects of polysaccharides from Portulaca oleracea L. Chemical and Pharmaceutical Bulletin, 58(4),507-510 https://doi.org/10.1248/cpb.58.507

62. Ebeye, O.A., Ekundina, V.O., Ekele, C.M. and Eboh, D.E.O., 2015. The histological effect of Cnidoscolus aconitifolius aqueous leaf extracts on the archetecture of the ovary, testis and sperm cells of adult wistar rats. International Journal of Herbs and Pharmacological Research, 4(1), 7-17.

63. Sardana, R. K., Chhikara, N., Tanwar, B., \& Panghal, A. (2018). Dietary impact on esophageal cancer in humans: a review. Food \& function, 9(4), 1967-1977. https://doi.org/10.1039/c7fo01908d

64. Oni, O. O., J. O. Alabi, M. A. Adewole, and A. A. Adegbenjo. "Effect of phytobiotics (mixture of garlic, ginger and chaya leaf) on growth performance, haematological and biochemical indices of pullet chicks." Slovak Journal of Animal Science 51, no. 2 (2018): 69-78.

65. Donkoh, A., Atuahene, C.C., Poku-Prempeh, Y.B. and Twum, I.G., 1999. The nutritive value of chaya leaf meal (Cnidoscolus aconitifolius (Mill.) Johnston): studies with broiler chickens. Animal Feed Science and Technology, 77(1-2), 163172. https://doi.org/10.1016/s0377-8401(98)00231-4

66. Oleforuh-Okoleh, V. U., G. C. Chukwu, and A. I. Adeolu. "Effect of ground ginger and garlic on the growth performance, carcass quality and economics of production of broiler chickens." Glob. J. Biosci. Biotechnol 3, no. 3 (2014): 225-229.

67. Ross-Ibarra, Jeffrey, and Alvaro Molina-Cruz. "The ethnobotany of chaya (Cnidoscolus aconitifolius ssp. aconitifolius Breckon): a nutritious maya vegetable." Economic Botany 56, no. 4 (2002): 350-365. https://doi.org/10.1663/00130001(2002)056[0350:TEOCCA]2.0 . $\mathrm{CO} ; 2$

68. Munsell, H.E., Williams, L.O., Guild, L.P., Troescher, C.B., Nightingale, G. and Harris, R.S., 1949. Composition of food 
plants of Central America. 1. Honduras. Food Research, 14,144164. https://doi.org/10.111/j.1365-2621.1950.tb16722.x

69. Kuti, J.O. and Konoru, H.B., 2006. Cyanogenic glycosides content in two edible leaves of tree spinach (Cnidoscolus spp.). Journal of Food Composition and Analysis, 19(6-7), 556561. https://doi.org/10.1016/j.jfca.2006.01.006

70. González-Laredo, R. F., ME Flores De La Hoya, M. J. QuinteroRamos, and J. J. Karchesy. "Flavonoid and cyanogenic contents of chaya (spinach tree)." Plant Foods for Human Nutrition 58, no. 3 (2003): 1-8.

https://doi.org/10.1023/B:QUAL.0000041142.48726.07

71. Lennox, J.A. and John, G.E., 2018. Proximate Composition, Antinutrient Content and Antimicrobial Properties of Cnidoscolus aconitifolius Leaves. Asian Food Science Journal, 16. https://doi.org/10.9734/AFSJ/2018/45055

72. Jones, D.A. and Ramnani, A.D., 1985. Altruism and movement of plants. Evolutionary theory, 7(3), 143-148.

73. Cereda, M.P. and Mattos, M.C.Y., 1996. Linamarin: the toxic compound of cassava. Journal of Venomous Animals and Toxins, 2(1), 06-12.

https://doi.org/10.1590/\$0104-79301996000100002

74. Akachukwu, D., Okafor, P.N. and Ibegbulem, C.O., 2014. Phytochemical content of Cnidoscolus aconitifolius leaves and toxicological effect of its aqueous leaf extract in Wistar rats. American Journal of Physiology, Biochemistry and Pharmacology, 3(1), 26-31. https://doi.org/10.5455/jib.20140504023102

75. Abayomi, O. E., Olorunfemi, E.O. and Mikailu, S., 2014. Phytochemical Analysis of Cnidoscolus aconitifolius (Euphorbiaceae) leaf with Spectrometric Techniques. Nigerian Journal of Pharmaceutical and Applied Science Research, 3(1), 38-49.

76. Oyagbemi, A.A., Odetola, A.A. and Azeez, O.I., 2011. Phytochemical investigation and proximate analysis on the leaves of Cnidoscolus aconitifolius. Journal of medicinal food, 14(3), 322-324. https://doi.org/10.1089/jmf.2008.0321

77. Kuti, J.O. and Kuti, H.O., 1999. Proximate composition and mineral content of two edible species of Cnidoscolus (tree spinach). Plant Foods for Human Nutrition, 53(4), 275-283. https://doi.org/10.1023/a:1008081501857

78. Kozlowska, A. and Szostak-Wegierek, D., 2014. Flavonoids-food sources and health benefits. Roczniki Państwowego Zakładu Higieny, 65(2), 79-85.

79. Lamien-Meda, Aline, Monika Nell, Ulrike Lohwasser, Andreas Börner, Chlodwig Franz, and Johannes Novak. "Investigation of antioxidant and rosmarinic acid variation in the sage collection of the genebank in Gatersleben." Journal of agricultural and food chemistry 58, no. 6 (2010): 3813-3819.

https://doi.org/10.1021/jf903993f

80. Shittu, S.A., Olayiwola, O.A. and Adebayo, O.R., 2014. Nutritional composition and phytochemical constituents of the leaves of Cnidoscolous. American Journal of Food Science and Nutrition Research, 1(2), 8-12.

81. Ferraz, C.A.A., de Oliveira, A.P., Ara, C.S., da Silva Oliveira, L.F., Picot, L., Ara, L., Rolim-Neto, P.J. and da Silva Almeida, J.R.G., 2018. Phytochemical and pharmacological aspects of Cnidoscolus poh/ species: a systematic

review. Phytomedicine, 50, 137-147

https://doi.org/10.1016/j.phymed.2017.08.017

82. Miranda-Velasquez, L., Oranday-Cardenas, A., Lozano-Garza, H., Rivas-Morales, C., Chamorro-Cevallos, G. and Cruz-Vega, D.E., 2010. Hypocholesterolemic activity from the leaf extracts of Cnidoscolus chayamansa. Plant foods for human nutrition, 65(4), 392-395. https://doi.org/10.1007/s11130-010-0202-4

83. Saba, A. B., A. A. Oyagbemi, and O. I. Azeez. "Amelioration of carbon tetrachloride-induced hepatotoxicity and haemotoxicity by aqueous leaf extract of Cnidoscolus aconitifolius in rats." Nigerian Journal of Physiological Sciences 25, no. 2 (2010): 139-147.

84. Moura, L. F. W. G., da Silva Neto, J. X., Lopes, T. D. P., Benjamin, S. R., Brito, F. C. R., Magalhães, F. E. A., ... \& Guedes, M. I. F. (2019). Ethnobotanic, phytochemical uses and ethnopharmacological profile of genus Cnidoscolus spp.(Euphorbiaceae): A comprehensive overview. Biomedicine \& Pharmacotherapy, 109, 1670-1679. https://doi.org/10.1016/j.biopha.2018.10.015

85. Otitolaiye, C. A., and C. Asokan. "GC-MS analysis of Cnidoscolus aconitifolius leaf aqueous extracts." Int J Sci Res 6, no. 7 (2016): 8376-81.

86. Obichi, E.A., Monago, C.C. and Belonwu, D.C., 2015. Effect of Cnidoscolus aconitifolius (Family Euphorbiaceae) aqueous leaf extract on some antioxidant enzymes and haematological parameters of high fat diet and Streptozotocin induced diabetic wistar albino rats. Journal of Applied Sciences and Environmental Management, 19(2), 201-209. https://doi.org/10.4314/jasem.v19i2.5

87. Oladeinde, F.O., Kinyua, A.M., Laditan, A.A., Michelin, R., Bryant, J.L., Denaro, F., Makinde, J.M., Williams, A.L., Kennedy, A.P. and Bronner, Y., 2007. Effect of Cnidoscolus aconitifolius leaf extract on the blood glucose and insulin levels of inbred type 2 diabetic mice. Cellular and Molecular Biology, 53(3), 3441. 